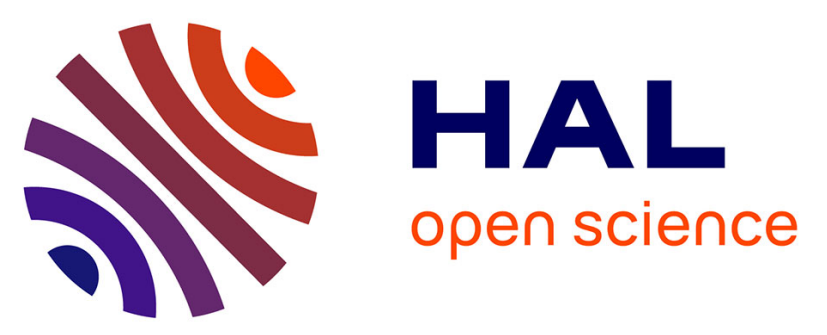

\title{
Why comparison between different chemical extraction procedures is necessary to better assess the metals availability in sediments
}

\author{
Alicia Cuvier, Lydia Leleyter, Anne Probst, Jean-Luc Probst, Jonathan \\ Prunier, Laurent Pourcelot, Gaël Le Roux, Mélanie Lemoine, M. Reinert, \\ Fabienne Baraud
}

\section{To cite this version:}

Alicia Cuvier, Lydia Leleyter, Anne Probst, Jean-Luc Probst, Jonathan Prunier, et al.. Why comparison between different chemical extraction procedures is necessary to better assess the metals availability in sediments. Journal of Geochemical Exploration, 2021, 225, pp.106762. 10.1016/j.gexplo.2021.106762 . hal-03181584

\section{HAL Id: hal-03181584 \\ https://hal.science/hal-03181584}

Submitted on 25 Mar 2021

HAL is a multi-disciplinary open access archive for the deposit and dissemination of scientific research documents, whether they are published or not. The documents may come from teaching and research institutions in France or abroad, or from public or private research centers.
L'archive ouverte pluridisciplinaire $\mathbf{H A L}$, est destinée au dépôt et à la diffusion de documents scientifiques de niveau recherche, publiés ou non, émanant des établissements d'enseignement et de recherche français ou étrangers, des laboratoires publics ou privés. 


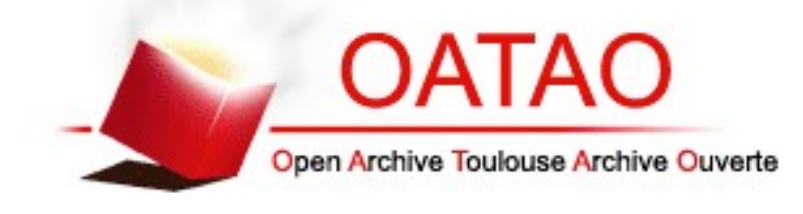

Open Archive Toulouse Archive Ouverte

OATAO is an open access repository that collects the work of Toulouse researchers and makes it freely available over the web where possible

This is an author's version published in: https://oatao.univ-toulouse.fr/27646

Official URL :

https://doi.org/10.1016/j.gexplo.2021.106762

To cite this version:
Cuvier, Alicia and Leleyter, Lydia and Probst, Anne and Probst,
Jean-Luc and Prunier, Jonathan and Pourcelot, Laurent and Le
Roux, Gaël and Lemoine, Mélanie and Reinert, M. and Baraud,
Fabienne Why comparison between different chemical extraction
procedures is necessary to better assess the metals availability in
sediments. (2021) Journal of Geochemical Exploration, 225.
106762. ISSN 0375-6742

Any correspondence concerning this service should be sent to the repository administrator: tech-oatao@listes-diff.inp-toulouse.fr 


\title{
Why comparison between different chemical extraction procedures is necessary to better assess the metals availability in sediments
}

\author{
A. Cuvier ${ }^{\mathrm{a}, \mathrm{b}}$, L. Leleyter ${ }^{\mathrm{c}, *}$, A. Probst ${ }^{\mathrm{a}}$, J.-L. Probst ${ }^{\mathrm{a}}$, J. Prunier ${ }^{\mathrm{d}}$, L. Pourcelot ${ }^{\mathrm{b}}$, G. Le Roux ${ }^{\mathrm{a}}$, \\ M. Lemoine ${ }^{c}$, M. Reinert ${ }^{c}$, F. Baraud ${ }^{c}$ \\ ${ }^{a}$ EcoLab, Université de Toulouse, CNRS, INPT, UPS, Toulouse, France \\ ${ }^{\mathrm{b}}$ IRSN/PRP-ENV/SESURE/Laboratoire d'études radioécologiques en milieu continental et marin, BP 113108 Saint Paul Lez Durance Cedex, France \\ ${ }^{\mathrm{c}}$ Normandie Univ, UNICAEN, ABTE, 14000 Caen, France \\ d Observatoire Midi-Pyrénées, laboratoire Géosciences Environnement Toulouse, CNRS/IRD/Université Paul Sabatier, 14 avenue Edouard Belin, 31400 Toulouse, France
}

\section{A R T I C L E I N F O}

\section{Keywords:}

Trace elements

Environmental availability

Chemical extractions

\begin{abstract}
A B S T R A C T
Single and sequential extractions are current and useful tools for estimating the availability of metals in soils or sediments. Many chemical extraction procedures have been proposed in the literature, making the comparison difficult. This study compares the data consistency of the potential availability given by four chemical extractions commonly found in the literature:

$\triangleright$ two single procedures (using dilute $\mathrm{HCl}$ or EDTA as reactant)

$\triangleright$ two sequential procedures (the modified standardized 3-steps procedure of the Standards, Measurements and Testing Programme (SMTP), namely BCR-extraction, and the 7-steps procedure of Leleyter and Probst (1999), namely LP-extraction).

The leaching procedures are all performed on the reference lake sediment CRM BCR-701, used as a reference to assess the accuracy of the modified standardized procedure of Rauret et al. (1999). The results show similar availabilities between $\mathrm{HCl}$ and EDTA single leaches for $\mathrm{Zn}, \mathrm{Cu}, \mathrm{Cr}$ and $\mathrm{Pb}$ and between $\mathrm{HCl}$ and the BCR procedures for $\mathrm{Zn}, \mathrm{Cu}, \mathrm{Cr}$ and $\mathrm{Ni}$. The LP-extraction is the most aggressive of the four tested procedures (except for $\mathrm{Pb}$ extraction), mainly due to a better extraction of the exchangeable fraction, by a better dissolution of the acidosoluble phase and particularly to a better dissolution of the amorphous and crystalline Fe-oxides. The comparison between the four procedures reveals a major problem of $\mathrm{Pb}$ extraction, potentially due to the formation of lead precipitates during $\mathrm{HCl}$ and the LP-extractions, even if an overestimation of the lead availability by the BCR procedure cannot be excluded.
\end{abstract}

\section{Introduction}

In soils and sediments, metals and metalloids are distributed between different geochemical fractions, according to their nature, their chemical speciation and their reactivity. In order to assess their distribution between residual and non-residual fractions and their environmental availability i.e. their ability to be available to living organisms in case of changes of environmental parameters, many authors use chemical extractions (Da Silva et al., 2002; Giancoli Barreto et al., 2004; Gismera et al., 2004; El-Azim and El-Moselhy, 2005; Singh et al., 2005). Those procedures are based on the ion-exchange reactions, the dissolution of the compounds of the solid phase and the selectivity and specificity of the used chemical reagents. Depending on the purpose of the study, two kinds of extractions are possible: single or sequential extractions.

Single extractions are rapid, simple and cost-effective ways to investigate the labile metal fraction of soils and sediments. Reagents used generally fall into three categories: acids, un-buffered salts and complexing reagents (Leleyter et al., 2012; Leleyter, 2017). Dilute strong acids are often used to estimate the mobile fractions of soils or sediments (Agemian and Chau, 1976). They partially extract exchangeable elements and dissolved trace elements associated with carbonate, Fe/Mnoxides and organic matter fractions (Rauret, 1998) and thus do not have a great selectivity. Among them, hydrochloric acid has been extensively used (Yu et al., 2021). It is assumed to extract metals due to

\footnotetext{
* Corresponding author.

E-mail address: lydia.reinert@unicaen.fr (L. Leleyter).
} 
its acidic properties combined with the chelating properties of $\mathrm{Cl}^{-}$. The extraction efficiency of $\mathrm{HCl}$ is dependent on the concentration and extraction time (Snape et al., 2004; Yu et al., 2021). The HCl concentrations differ within separate studies: 0.1 M (Giancoli Barreto et al., 2004; Yu et al., 2004; Wei et al., 2005; Menzies et al., 2007; Hyeop-Jo Han et al., 2020; Fu et al., 2020; Gil-Díaz et al., 2021), 0.2 M (Kuo et al., 2006; Leleyter et al., 2012), 0.5 M (Agemian and Chau, 1976; Gaiero et al., 2003; Sutherland et al., 2004) or 1 M (Snape et al., 2004; Hamdoun et al., 2015b; Yu et al., 2021). EDTA is one of the most widely used complexing reagent because of its high extraction capacity (Sahuquillo et al., 2003). It is assumed to extract metals on exchange sites on both inorganic and organic complexes. However, it can also dissolve calcareous material and apatite minerals through the complexation of calcium and magnesium (Chao, 1984; Sahuquillo et al., 2003; Gismera et al., 2004). Most authors use the same EDTA concentration value (0.05 M) (McCready et al., 2003; Camizuli et al., 2014; Hamdoun et al., 2015b; Sow et al., 2018; Avumadi et al., 2019; Benabdelkader et al., 2019), even if 0.02 M EDTA is also reported (Gismera et al., 2004).

Sequential extractions procedures (SEP) are based on the use of several reagents applied to a solid sample aliquot. Successive specific leaching of geochemical fractions is performed, from the least aggressive to the most destructive reactants. Contrary to the single extractions, those procedures allow to characterize the different mobile fractions, even if they do not give any direct information about mineralogy. Various protocols were described in the literature (see review in Filgueiras et al., 2002 and Gleyzes et al., 2002). That is why in the framework of the Standards, Measurements and Testing Programme (SMTP), Quevauviller et al. (1994) then Rauret et al. (1999) proposed an harmonization of extraction protocols and achieved to a standardized 3steps procedure (the BCR-extraction) which selectivity, reproducibility and repeatability were confirmed by further studies (Whalley and Grant, 1994; Davidson et al., 1998; Rauret et al., 1999). In this procedure, various certified materials (CRM 483, 601, 700 and 701) can be used in order to validate the extraction process (Quevauviller, 2002). This protocol has been widely adopted and applied to diverse media (see review in Sutherland, 2010; Kumkrong et al., 2020 and references therein), in particular since it is a compromise between one-step leaches and other multi-steps procedures. However, this extraction scheme could lead to an underestimation of metal mobility (Caraballo et al., 2018) and does not provide detailed information to scientists as some of the other sequential extraction procedures (Alan and Kara, 2019). In spite of the criticisms of their lack of selectivity and processes of readsorption of elements (Gómez-Ariza et al., 2000; Gleyzes et al., 2002), sequential extraction protocols, and more generally chemical extractions, are commonly used through the literature, mainly because there are relatively easy to implement for most of laboratories (see review in Filgueiras et al., 2002).

The sequential extractions are widely considered as effective analytical procedures to estimate the geochemical forms of metals and metalloids present in soils and to provide information on their geogenic or anthropogenic origin as well as on their availability towards other environmental compartments (Naz et al., 2020; Khelifi et al., 2020). Naz et al. (2020) highlighted that the sequential extraction remains vital to assess and quantify the metal fractions/forms in the soil in order to understand the potential for metal uptake by plants, the bioavailable portion and its bioaccumulation. Gil-Díaz et al. (2021) reminded that most of the studies on risk assessment use metal(loid)s availability data from single or sequential extractions although the results may vary with the extractant solutions used. In their opinion, further studies comparing the metals availability estimated by various chemical procedures for a specific site are necessary. According Padoan et al. (2020), the use of chemical extractions provides useful indications to estimate the metals release to the environment in the case of flooding episodes.

Studies of selectivity must be applied to each new procedure or modification of existing procedures that is only weakly reported in the studies. To our knowledge, only Leleyter and Probst (1999) have developed an optimized sequential chemical extraction procedure, checked for efficiency, selectivity, reproducibility and repeatability of the different steps.

The objective of the present paper is to check the consistency of data on the mobility and the partitioning of $\mathrm{Cr}, \mathrm{Cu}, \mathrm{Ni}, \mathrm{Pb}$ and $\mathrm{Zn}$ in the lake reference sediment (CMR code: BCR-701), given by four extraction procedures commonly found in the literature, i.e. two single extractions (dilute acid ( $\mathrm{HCl})$ and complexing agent (EDTA)) and two protocols of sequential extraction. The first one is the procedure from Leleyter and Probst (1999), frequently used on soils and sediments in various conditions (Leleyter and Probst, 1999; Aubert et al., 2004; Leleyter and Baraud, 2006; Cecchi et al., 2008; Salvarredy-Aranguren et al., 2008; Bur et al., 2009; N'Guessan et al., 2009; Leleyter et al., 2012; Seh-Bardan et al., 2012; El Azzi et al., 2013; Roussiez et al., 2013; Hamdoun et al., 2015a, 2015b; Baraud et al., 2017; Leleyter et al., 2018). The second one is the $\mathrm{BCR}$ procedure. Major elements such as $\mathrm{Al}, \mathrm{Fe}, \mathrm{Mn}$ and $\mathrm{Ca}$ are also investigated since those elements provide information on the dissolution of the major soil components, i.e. clays, oxides and carbonates.

\section{Material and methods}

\subsection{Extraction procedures}

All the reagents used to perform the extraction procedures or the mineralization of the total sample and the residual fraction are ultrapure grade and supplied by VWR®.

\subsubsection{Single extraction}

Two single extraction procedures are performed in triplicate on the BCR 701. The samples are shaken using a ratio 10:1 (liquid/solid), with either $0.5 \mathrm{~mol} \cdot \mathrm{L}^{-1} \mathrm{HCl}$ (Kubová et al., 2008) or $0.05 \mathrm{~mol} \cdot \mathrm{L}^{-1}$ EDTA (Chao, 1984), during $1 \mathrm{~h}$, at room temperature. Following centrifugation at $3000 \mathrm{~g}$ during $15 \mathrm{~min}$ then filtration at $0.45 \mu \mathrm{m}$ using PVDF hydrophilic membrane (HVLP filter), the solutions are stored at $4{ }^{\circ} \mathrm{C}$ until chemical analysis. The obtained labile fractions are named $\mathrm{HCl}-\mathrm{F}_{\text {lab }}$ and EDTA-F $F_{\text {lab}}$, respectively.

\subsubsection{Sequential extraction procedures}

Two procedures are applied in triplicate. The BCR-extraction is the three steps BCR sequential procedure described by Rauret et al. (1999) and Pueyo et al. (2001) (see Table 1). Extracts are centrifuged at $3000 \mathrm{~g}$ for $20 \mathrm{~min}$ and the supernatant is decanted and transferred in polypropylene containers previously washed with $0.37 \mathrm{~mol} \cdot \mathrm{L}^{-1} \mathrm{HNO}_{3}$. This procedure allows three operationally-defined non-residual fractions to be distinguished successively (BCR-F1 = acid-soluble, BCR-F2 = reducible, BCR-F3 = oxidizable) and one residual fraction (BCR-F4 = residual). The sum of BCR-F1 to F3 is the labile fraction, namely BCR$\mathrm{F}_{\text {lab. }}$.

The second procedure (LP-extraction) is the optimized sequential chemical extraction procedure developed by Leleyter and Probst (1999). This one allows seven non-residual mineralogical fractions to be distinguished successively (LP-F1a $=$ water soluble, LP-F1b = exchangeable, LP-F1c = acid-soluble, LP-F2a $=$ Mn-oxides, LP-F2b = amorphous Fe-oxides, LP-F2c = crystalline Fe-oxides, LP-F3 = oxidizable) and the residual fraction (LP-F4 = residual). Details on the reactants and on the physico-chemical parameters of each step are indicated in Table 1. After each step, extracts are filtrated through a $0.45 \mu \mathrm{m}$ HVLP filter. Filtrates are transferred in polypropylene containers previously washed with $2 \% \mathrm{HNO}_{3}$. The sum of the 7 non-residual fractions (LP F1 to F3) is the labile fraction, namely LP-F $\mathrm{F}_{\text {lab. Following }}$ each step of both procedures, the solutions were stored at $4{ }^{\circ} \mathrm{C}$ until chemical analysis.

On the residue as well on the bulk sample, a four acids digestion procedure is applied as described below and in Table 1 . Total digestion is performed as the following steps: 
Table 1

Sequential extraction performed according to the procedures of Rauret et al. (1999) and Leleyter and Probst (1999). RT: room temperature.

\begin{tabular}{|c|c|c|c|c|c|c|c|}
\hline \multicolumn{2}{|c|}{ Desired fraction } & \multicolumn{2}{|l|}{ Extractive reagent } & \multicolumn{2}{|c|}{ Reaction time and temperature } & \multicolumn{2}{|c|}{ Reagent/sample ratio } \\
\hline BCR & LP & BCR & LP & BCR & LP & BCR & LP \\
\hline $\begin{array}{l}\text { Rauret } \\
\text { et al., } 1999\end{array}$ & $\begin{array}{l}\text { Leleyter and } \\
\text { Probst, } 1999\end{array}$ & Rauret et al., 1999 & Leleyter and Probst, 1999 & Rauret et al., 1999 & $\begin{array}{l}\text { Leleyter and } \\
\text { Probst, } 1999\end{array}$ & $\begin{array}{l}\text { Rauret } \\
\text { et al., } 1999\end{array}$ & $\begin{array}{l}\text { Leleyter and } \\
\text { Probst, } 1999\end{array}$ \\
\hline \multirow[t]{3}{*}{$\begin{array}{l}\text { F1 = acid- } \\
\text { soluble }\end{array}$} & $\begin{array}{l}\text { F1a = water- } \\
\text { soluble }\end{array}$ & $\begin{array}{l}0.11 \mathrm{M} \mathrm{CH}_{3} \mathrm{COOH}(\mathrm{pH} \\
2-3)\end{array}$ & Milli Q water (pH 5.7) & $16 \mathrm{~h}, \mathrm{RT}$ & $30 \mathrm{~min}, \mathrm{RT}$ & $40: 1$ & $20: 1$ \\
\hline & $\begin{array}{l}\mathrm{F} 1 \mathrm{~b}= \\
\text { exchangeable }\end{array}$ & & $1 \mathrm{M} \mathrm{Mg}\left(\mathrm{NO}_{3}\right)_{2}$ (pH 5) & & $2 \mathrm{~h}, \mathrm{RT}$ & & $10: 1$ \\
\hline & $\begin{array}{l}\text { F1c }=\text { acido- } \\
\text { soluble }\end{array}$ & & $1 \mathrm{M} \mathrm{NaOAc/HOAc}(\mathrm{pH} 4.5)$ & & $5 \mathrm{~h}, \mathrm{RT}$ & & $10: 1$ \\
\hline \multirow{3}{*}{$\begin{array}{l}\mathrm{F} 2= \\
\quad \text { reducible }\end{array}$} & F2a $=$ Mn-oxides & $0.5 \mathrm{M} \mathrm{NH}_{2} \mathrm{OH} \cdot \mathrm{HCl}(\mathrm{pH}$ & $0.1 \mathrm{M} \mathrm{NH}_{2} \mathrm{OH} \cdot \mathrm{HCl}(\mathrm{pH} 3.5)$ & $16 \mathrm{~h}, \mathrm{RT}$ & $30 \mathrm{~min}, \mathrm{RT}$ & $40: 1$ & $10: 1$ \\
\hline & $\begin{array}{l}\mathrm{F} 2 \mathrm{~b}=\text { amorphous } \\
\text { Fe-oxides }\end{array}$ & 1.5 with $\mathrm{HNO}_{3}$ ) & $\begin{array}{l}0.2 \mathrm{M}\left(\mathrm{NH}_{4}\right) \mathrm{C}_{2} \mathrm{O}_{4} / \mathrm{H}_{2} \mathrm{C}_{2} \mathrm{O}_{4} \\
(\mathrm{pH} \mathrm{3)}\end{array}$ & & $4 \mathrm{~h}, \mathrm{RT}$, in dark & & $10: 1$ \\
\hline & $\begin{array}{l}\mathrm{F} 2 \mathrm{c}=\text { crystalline } \\
\text { Fe-oxides }\end{array}$ & & $\begin{array}{l}0.2 \mathrm{M}\left(\mathrm{NH}_{4}\right) \mathrm{C}_{2} \mathrm{O}_{4} / \mathrm{H}_{2} \mathrm{C}_{2} \mathrm{O}_{4}+ \\
0.1 \mathrm{M} \mathrm{C}_{6} \mathrm{H}_{8} \mathrm{O}_{6}(\mathrm{pH} 2.3)\end{array}$ & & $30 \mathrm{~min}, 85^{\circ} \mathrm{C}$ & & $10: 1$ \\
\hline $\begin{array}{l}\mathrm{F} 3= \\
\quad \text { oxidizable }\end{array}$ & F3 = oxidizable & $\begin{array}{l}\text { - } 30 \% \mathrm{H}_{2} \mathrm{O}_{2}(\mathrm{pH} 2-3) \\
\text { - } 30 \% \mathrm{H}_{2} \mathrm{O}_{2}(\mathrm{pH} 2-3) \\
\text { - } 1 \mathrm{M} \mathrm{NH}_{4} \mathrm{OAc}(\mathrm{pH} 2 \\
\left.\text { with } \mathrm{HNO}_{3}\right)\end{array}$ & $\begin{array}{l}-0.02 \mathrm{M} \mathrm{HNO}_{3}+30 \% \mathrm{H}_{2} \mathrm{O}_{2} \\
\text { - } 3.2 \mathrm{M} \mathrm{NH}_{4} \mathrm{OAc}+20 \% \\
\mathrm{HNO}_{3}(\mathrm{pH} 2)+\text { Milli Q water }\end{array}$ & $\begin{array}{l}-1 \mathrm{~h} \text {, room } \\
\text { temperature }+1 \mathrm{~h} \text {, } \\
85^{\circ} \mathrm{C} \\
-1 \mathrm{~h}, 85^{\circ} \mathrm{C} \\
-16 \mathrm{~h} \text {, room } \\
\text { temperature }\end{array}$ & $\begin{array}{l}\text { - } 5 \mathrm{~h}, 85^{\circ} \mathrm{C} \\
\text { - } 30 \mathrm{~min}, 85^{\circ} \mathrm{C}\end{array}$ & $\begin{array}{l}10: 1 \\
10: 1 \\
50: 1\end{array}$ & $\begin{array}{l}11: 1 \\
20: 1\end{array}$ \\
\hline \multicolumn{2}{|c|}{ Residue and bulk sample } & \multicolumn{2}{|c|}{$\begin{array}{l}\text { - } \mathrm{HF} / \mathrm{HNO}_{3} / \mathrm{H}_{2} \mathrm{O}_{2} \\
\text { - } \mathrm{HClO}_{4} \\
\text { - } \mathrm{H}_{3} \mathrm{BO}_{3}+\mathrm{HCl} 6 \mathrm{~N}+\text { Milli Q water } \\
\text { - } \mathrm{HNO}_{3} 7.5\end{array}$} & \multicolumn{2}{|c|}{$\begin{array}{l}\text { - } 2 \text { days, } 70{ }^{\circ} \mathrm{C} \\
\text { - } 2 \text { days, } 120^{\circ} \mathrm{C} \\
\text { - } 1 \text { day }+1 \text { night, } 110{ }^{\circ} \mathrm{C} \\
\text { - } 1 \text { day, } 70{ }^{\circ} \mathrm{C}\end{array}$} & \multicolumn{2}{|c|}{$\begin{array}{l}\text { - } 4 \mathrm{~mL}+1 \mathrm{~mL}+0.5 \mathrm{~mL} \\
\text { - } 1 \mathrm{~mL} \\
\text { - } 1 \mathrm{~mL}+2 \mathrm{~mL}+3 \mathrm{~mL} \\
\text { - } 10 \mathrm{~mL}\end{array}$} \\
\hline
\end{tabular}

1. Microwave digestion of $0.250 \mathrm{~g}$ of dry residue or bulk sample with a solution of $\mathrm{HF} / \mathrm{HNO}_{3} / \mathrm{HCl}$ during $20 \mathrm{~min}$ at $200{ }^{\circ} \mathrm{C}$

2. Evaporation of the mixture at $70{ }^{\circ} \mathrm{C}$.

3. Dissolution and homogenization of the dry residue in $1 \mathrm{~mL}$ of $\mathrm{HClO}_{4}$ $+\mathrm{H}_{2} \mathrm{O}_{2} 30 \% v / \mathrm{v}$, heating at $120^{\circ}$ during 2 days.

4. After cooling, evaporation of the mixture in 3 drying steps: $8 \mathrm{~h}$ at $120^{\circ} \mathrm{C}, 12 \mathrm{~h}$ at $165^{\circ} \mathrm{C}$ and $1-2 \mathrm{~h}$ at $190^{\circ} \mathrm{C}$ to avoid to form fluorides which could coprecipitate trace elements and to be insoluble (Yokoyama et al., 1999).

5. Dissolution and homogenization of the dry residue in $1 \mathrm{~mL}$ of $\mathrm{H}_{3} \mathrm{BrO}_{4}+2 \mathrm{~mL}$ of $\mathrm{HCl} 6 \mathrm{~mol} \cdot \mathrm{L}^{-1}+3 \mathrm{~mL}$ of MQ Water, heating at $110^{\circ}$ during 1 day +1 night

6. Evaporation of the solution at $70{ }^{\circ} \mathrm{C}$.

7. Dissolution and homogenization of the dry residue in $10 \mathrm{~mL}$ of $\mathrm{HNO}_{3}$ $7,5 \mathrm{~mol} \cdot \mathrm{L}^{-1}$, heating at $70{ }^{\circ} \mathrm{C}$ during 1 day

8. Storage at $4{ }^{\circ} \mathrm{C}$ until chemical analysis.

\subsection{Certified reference sediment}

Single and sequential extractions are performed on the certified reference material BCR-701. This material has been collected from Lake Orta (Piemonte, Italy), which is known for serious metal contamination due to industrial discharges (Provini and Gaggino, 1986; Baudo et al., 1989). Details on the preparation and the certification of the BCR-701 sediment are found in Pueyo et al. (2001), Quevauviller (2002) and Kubová et al. (2004). Certified concentrations of $\mathrm{Cr}, \mathrm{Cu}, \mathrm{Ni}, \mathrm{Pb}$ and $\mathrm{Zn}$ for each step of the BCR are given in Tables 2 and 3. Certified concentrations in the residue and the bulk sample, obtained after aqua regia extraction, are indicated in Pueyo et al. (2001) and Kubová et al. (2004).

\subsection{Chemical analysis}

Major and trace elements contents (Al, Ca, Fe, $\mathrm{Mn}, \mathrm{Cr}, \mathrm{Cu}, \mathrm{Ni}, \mathrm{Pb}$ and $\mathrm{Zn}$ ) of leachates from the single extractions and the LP-extraction, as well as the residue, are carried out using inductively coupled plasma atomic emission spectrometry (ICP-AES; Varian Vista-MPX). The quality control of ICP-AES analyses is assessed by the analysis of blank reagents and calibration standards, prepared with commercially available solutions (Varian standard solutions). Accuracy of ICP-AES measurements is determined with various certified reference materials (Rousseau et al., 2009; Gabelle et al., 2012; Hamdoun et al., 2015a, 2015b). The detection limits (LD) range from $0.09 \mu \mathrm{g} \cdot \mathrm{L}^{-1}$ to $8 \mu \mathrm{g} \cdot \mathrm{L}^{-1}$, depending on the element.

Major element (Al, Ca, Fe and Mn) contents of supernatants from the BCR-extraction are analyzed by ICP-AES (Thermo IRIS INTREPID II $\mathrm{XDL})$, while trace elements $(\mathrm{Cr}, \mathrm{Cu}, \mathrm{Ni}, \mathrm{Pb}$ and $\mathrm{Zn}$ ) are determined by ICP-MS (Agilent 7500) analyses. During the ICP-MS analyses, an internal standard, ${ }^{115} \mathrm{In} /{ }^{187} \mathrm{Re}$ of known concentration is added to all samples to correct the analyzer deviation. The detection limits vary around 0.2 $\mathrm{mg} \cdot \mathrm{L}^{-1}$ for ICP-AES and $0.01 \mu \mathrm{g} \cdot \mathrm{L}^{-1}$ for ICP-MS, depending on the element. The accuracy of the ICP-MS measurements is checked using natural river water (SLRS-5) (Yeghicheyan et al., 2013) and the measurement errors are typically lower than $5 \%$. All blanks were negligible

Table 2

Chemical composition in $\mathrm{mg} \cdot \mathrm{kg}^{-1}$ of dry soil of BCR 701 and recovery percentages calculated for both sequential extraction procedures. $* \%$ of recovery $=$ sum of all fractions $\left(\mathrm{mg} \cdot \mathrm{kg}^{-1}\right) /$ concentration in the bulk $\left(\mathrm{mg} \cdot \mathrm{kg}^{-1}\right) \times 100$; n.a. $=$ not available.

\begin{tabular}{|c|c|c|c|c|c|c|c|c|c|c|c|}
\hline Element & & $\begin{array}{l}\text { Digestion of the bulk } \\
\text { sample }\end{array}$ & $\mathrm{Cr}$ & $\mathrm{Cu}$ & $\mathrm{Ni}$ & $\mathrm{Pb}$ & $\mathrm{Zn}$ & $\mathrm{Al}$ & $\mathrm{Ca}$ & $\mathrm{Fe}$ & Mn \\
\hline \multirow[t]{2}{*}{$\begin{array}{l}\text { Total concentration } \\
\left(\mathrm{mg} \cdot \mathrm{kg}^{-1}\right)\end{array}$} & This study & See Table 1 & $\begin{array}{l}378 \pm \\
32\end{array}$ & $\begin{array}{l}309 \pm \\
42\end{array}$ & $\begin{array}{l}123 \pm \\
9\end{array}$ & $\begin{array}{l}164 \pm \\
11\end{array}$ & $\begin{array}{l}518 \pm \\
64\end{array}$ & $\begin{array}{l}77,805 \pm \\
4567\end{array}$ & $\begin{array}{l}18,677 \pm \\
958\end{array}$ & $\begin{array}{l}38,177 \pm \\
2204\end{array}$ & $\begin{array}{l}792 \pm \\
84\end{array}$ \\
\hline & $\begin{array}{l}\text { Kubová et al., } \\
2004\end{array}$ & $\begin{array}{l}\mathrm{HF}+\mathrm{HNO}_{3}+ \\
\mathrm{HClO}_{4}+\mathrm{H}_{2} \mathrm{O}_{2}\end{array}$ & n.a. & $\begin{array}{l}279 \pm \\
5\end{array}$ & n.a. & $\begin{array}{l}155 \pm \\
2\end{array}$ & $\begin{array}{l}476 \pm \\
2\end{array}$ & $\begin{array}{l}71,470 \pm \\
150\end{array}$ & n.a. & $\begin{array}{l}38,580 \pm \\
290\end{array}$ & $\begin{array}{l}689 \pm \\
10\end{array}$ \\
\hline$\%$ of recovery ${ }^{\mathrm{a}}$ & $\begin{array}{l}\text { BCR } \\
\text { LP-extraction }\end{array}$ & & $\begin{array}{l}93 \pm 3 \\
109 \pm \\
4\end{array}$ & $\begin{array}{l}85 \pm 1 \\
112 \pm \\
4\end{array}$ & $\begin{array}{l}92 \pm 1 \\
106 \pm \\
3\end{array}$ & $\begin{array}{l}96 \pm 1 \\
109 \pm \\
3\end{array}$ & $\begin{array}{l}93 \pm 1 \\
118 \pm \\
3\end{array}$ & $\begin{array}{l}102 \pm 3 \\
100 \pm 7\end{array}$ & $\begin{array}{l}96 \pm 1 \\
106 \pm 3\end{array}$ & $\begin{array}{l}99 \pm 2 \\
93 \pm 2\end{array}$ & $\begin{array}{l}98 \pm 3 \\
113 \pm \\
3\end{array}$ \\
\hline
\end{tabular}

a $\%$ of recovery $=$ sum of all fractions $\left(\mathrm{mg} \cdot \mathrm{kg}^{-1}\right) /$ concentration in the bulk $\left(\mathrm{mg} \cdot \mathrm{kg}^{-1}\right) \times 100$. 
Table 3

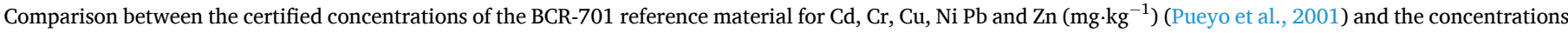
measured in this study and in Kubová et al. (2004), from the BCR-extraction. (na: not available).

\begin{tabular}{|c|c|c|c|c|c|c|c|c|c|}
\hline \multirow[t]{2}{*}{ Element } & \multicolumn{3}{|c|}{ Acid-soluble $\left(\mathrm{mg} \cdot \mathrm{kg}^{-1}\right)$} & \multicolumn{3}{|c|}{ Reducible $\left(\mathrm{mg} \cdot \mathrm{kg}^{-1}\right)$} & \multicolumn{3}{|c|}{ Oxidizable $\left(\mathrm{mg} \cdot \mathrm{kg}^{-1}\right)$} \\
\hline & Measured & $\begin{array}{l}\text { Kubová et al. } \\
\text { (2004) }\end{array}$ & $\begin{array}{l}\text { Certified Pueyo } \\
\text { et al. (2001) }\end{array}$ & Measured & $\begin{array}{l}\text { Kubová et al. } \\
\text { (2004) }\end{array}$ & $\begin{array}{l}\text { Certified Pueyo } \\
\text { et al. (2001) }\end{array}$ & Measured & $\begin{array}{l}\text { Kubová et al. } \\
\text { (2004) }\end{array}$ & $\begin{array}{l}\text { Certified Pueyo } \\
\text { et al. (2001) }\end{array}$ \\
\hline $\mathrm{Cr}$ & $2.6 \pm 0.5$ & na & $2.3 \pm 0.2$ & $36 \pm 7$ & na & $46 \pm 2$ & $156 \pm 9$ & na & $143 \pm 7$ \\
\hline $\mathrm{Cu}$ & $46 \pm 6$ & $51 \pm 1$ & $49 \pm 2$ & $129 \pm 9$ & $118 \pm 2$ & $124 \pm 3$ & $52 \pm 5$ & $60 \pm 1$ & $55 \pm 4$ \\
\hline $\mathrm{Ni}$ & $15 \pm 2$ & na & $15 \pm 1$ & $26 \pm 5$ & na & $27 \pm 2$ & $16 \pm 1$ & na & $15 \pm 1$ \\
\hline $\mathrm{Pb}$ & $3 \pm 0.5$ & $3 \pm 0.5$ & $3 \pm 0.5$ & $120 \pm 8$ & $128 \pm 1$ & $126 \pm 3$ & $8 \pm 1$ & $10 \pm 1$ & $9 \pm 2$ \\
\hline $\mathrm{Zn}$ & $197 \pm 18$ & $200 \pm 1$ & $205 \pm 6$ & $\begin{array}{l}104.3 \pm \\
6.4\end{array}$ & $118 \pm 2$ & $114 \pm 5$ & $48 \pm 3$ & $40 \pm 1$ & $46 \pm 4$ \\
\hline $\mathrm{Al}$ & $158 \pm 1$ & $182 \pm 2$ & na & $\begin{array}{l}2242 \pm \\
162\end{array}$ & $3526 \pm 46$ & na & $939 \pm 72$ & $1266 \pm 60$ & na \\
\hline $\mathrm{Fe}$ & $54 \pm 1$ & $71 \pm 1$ & na & $4432 \pm 35$ & $7698 \pm 106$ & na & $730 \pm 43$ & $1097 \pm 53$ & na \\
\hline $\mathrm{Ca}$ & $\begin{array}{l}7752 \pm \\
119\end{array}$ & na & na & $1990 \pm 36$ & na & na & $161 \pm 6$ & na & na \\
\hline Mn & $174 \pm 2$ & $170 \pm 1$ & na & $117 \pm 3$ & $125 \pm 2$ & na & $26 \pm 1$ & $23 \pm 1$ & na \\
\hline
\end{tabular}

(less than $10^{-4} \mathrm{mg} \cdot \mathrm{kg}^{-1}$ ).

\section{Results and discussion}

\subsection{Accuracy of the sequential extractions and of the bulk sample dissolution}

Results on total metal concentrations on the bulk sample are given in Table 2. Most of the total concentrations are higher than the previous published data (Kubová et al., 2004), this may be due to a better digestion of clays or other silicate minerals, as suggested by the higher value of $\mathrm{Al}$ (see Table 2).

The accuracy of each step of the BCR-extraction procedure is additionally confirmed by comparison with Kubová et al. (2004) analyses and certified values (Pueyo et al., 2001) (see Table 3).

An internal check is secondly performed by comparing the bulk total concentrations of the target elements and the sum of the sequential fractions (see Table 2). The percentages of recovery of all studied elements, i.e. $\mathrm{Al}, \mathrm{Ca}, \mathrm{Fe}, \mathrm{Mn}, \mathrm{Cr}, \mathrm{Cu}, \mathrm{Ni}, \mathrm{Pb}$ and $\mathrm{Zn}$, range from $85 \%$ to $118 \%$ for both procedures, indicating the results were reliable considering the uncertainties (Table 2).

\subsection{Comparison of the labile fractions extracted by the four procedures}

The so-called labile fraction is supposed to represent the environmentally available fraction of a specific element, if changes in the environment occur (Leleyter et al., 2012). In the leachates from the two sequential procedures and from the two single extractions, the so-called labile fraction is expressed by percentage values, which correspond to the ratio between the metal concentrations analyzed in the leachate and the total content determined in the bulk sample. Thus, for the sequential extractions, the percentage of the labile fraction, namely BCR-F $\mathrm{F}_{\text {lab }}$ and $\mathrm{LP}_{\mathrm{F}} \mathrm{F}_{\text {lab}}$, are the sum of respectively the three (BCR-extraction) and the seven (LP-extraction) non-residual fractions divided by the total content determined in the bulk sample.

The Fig. 1 compares the percentages of labile fractions from the four extraction procedures for the target elements. Calculation of the standard deviation (SD) underlines that both sequential extraction procedures are very reproducible, since the values of SD range from 1 to $8 \%$, depending on the elements (Fig. 1). The SD values of both single leaching procedures are correct but slightly higher since the values range from 1 to $12 \%$ depending on the element, involving a heterogeneity of the distribution of this element in the sampled aliquots (Fig. 1).

Among the major elements, $\mathrm{Al}$ is poorly mobilized by the four procedures $(\leq 12 \%)$, indicating that the major part of $\mathrm{Al}$ remains trapped in the residual fraction since the reagents do not affect the alumino-silicate

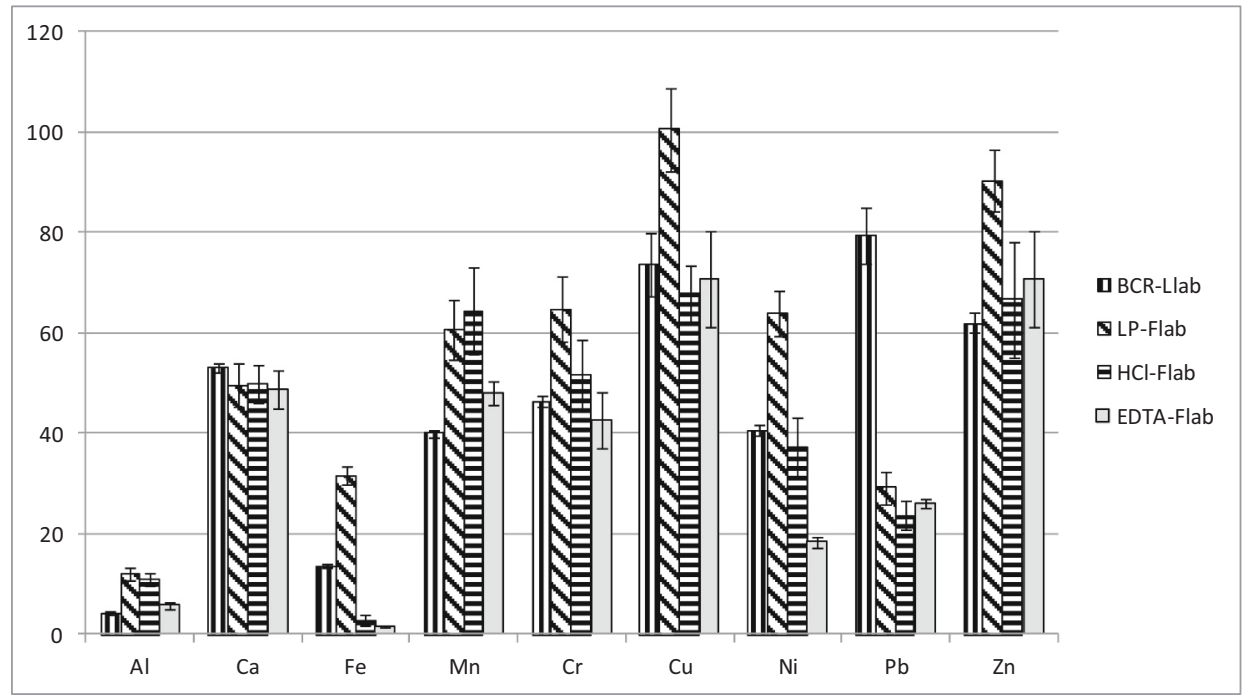

Fig. 1. Percentage of labile metal from single $\left(\mathrm{HCl}-\mathrm{F}_{\mathrm{lab}}\right.$ or $\left.\mathrm{EDTA}-\mathrm{F}_{\mathrm{lab}}\right)$ and sequential $\left(\mathrm{BCR}-\mathrm{F}_{\mathrm{lab}}\right.$ or $\left.\mathrm{LP}-\mathrm{F}_{\mathrm{lab}}\right)$ extractions. Uncertainties are calculated from the triplicates. 
lattices (Leleyter and Probst, 1999; Sutherland, 2002; Leleyter and Baraud, 2005). The percentages of extracted Ca are similar for the four procedures (from $49 \%$ to $53 \%$ ). Whereas $\mathrm{Fe}$ is poorly extracted by the both single extractions $(<3 \%)$, confirming that the dissolution of Feoxides by $\mathrm{HCl}$ or EDTA is limited. On the contrary, the percentage of extracted Fe strongly increases for the sequential procedures (from 14\% (BCR) to $32 \%$ (LP-extraction)) with respect to the single extractions. According to Sutherland et al. (2004) who showed that the $0.5 \mathrm{M} \mathrm{HCl}$ single leaching can be far more aggressive than the BCR, the extracted percentage of $\mathrm{Mn}$ is relatively comparable between EDTA-F $\mathrm{F}_{\text {lab }}$ and BCR$\mathrm{F}_{\mathrm{lab}}(48 \%$ and $40 \%$ respectively), but is far more important in the two other procedures $\left(64 \%\right.$ and $61 \%$ for $\mathrm{HCl}-\mathrm{F}_{\mathrm{lab}}$ and $\mathrm{LP}-\mathrm{F}_{\mathrm{lab}}$ respectively) suggesting that only LP-extraction is able to solubilize all the iron and manganese oxides.

Regarding the trace elements, three groups can be identified, depending on their behavior with regard to the leaching procedures (Fig. 1):

$>\mathrm{Pb}$ is better extracted by $\mathrm{BCR}\left(\mathrm{BCR}-\mathrm{F}_{\text {lab }}=79 \%\right)$ than by the three others procedures (between 24 and 29\%).

$>$ the percentage of Ni extracted is similar in HCl- $\mathrm{F}_{\text {lab }}$ and BCR-F $\mathrm{F}_{\mathrm{lab}}$ ( $37 \% \%$ and $41 \%$ respectively), but is lower compared with the value of LP-F lab $(64 \%)$, whereas only $18 \%$ is extracted by EDTA. This result agree with the conclusion from Madrid et al. (2007) that only a small proportion of the metals accessible to the BCR reagents were likely to be soluble in EDTA.

$>$ the percentages of $\mathrm{Zn}, \mathrm{Cr}$ and $\mathrm{Cu}$ extracted are higher in LP-Flab than in the labile fractions extracted by the other procedures $\left(\mathrm{HCl}-\mathrm{F}_{\mathrm{lab}}\right.$, EDTA-F $\mathrm{F}_{\mathrm{lab}}$ and BCR-F $\mathrm{F}_{\mathrm{ab}}$ ) for which the extraction rates are similar for each element. Kubová et al. (2004, 2008) already published that the percentage values of $\mathrm{HCl}$ single extraction and $\mathrm{BCR}_{\text {lab }}$ are very closed for $\mathrm{Cr}, \mathrm{Cu}$ and $\mathrm{Zn}$. But on the contrary, Madrid et al. (2007) concluded that dilute $\mathrm{HCl}$ was not a viable alternative to the BCR for the estimation of the potential mobility and extractability of trace elements in urban soils. Sahuquillo et al. (2003) wrote that the relatively high extractability of Cu by EDTA can be explained by its high complexation constant with EDTA $(\log K=17.8)$ and by its remobilization from the complexation of $\mathrm{Fe}$ from oxides and hydroxides and organic matter with EDTA.

Acids are supposed to leach elements associated to carbonates and oxides (Juste, 1989; Baize, 1997). The acid role on the extraction was evaluated by comparing the $0.5 \mathrm{~mol} \cdot \mathrm{L}^{-1} \mathrm{HCl}$ extraction and the sums of the acido-soluble and the reducible steps of the sequential extractions but no significant correlation was found. In the same way, EDTA is expected to leach elements from oxides and organic matter (Juste, 1989; Baize, 1997) or from acido-soluble and oxidizable fractions (Ure et al., 1995). However, as previously shown by Leleyter and Baraud (2005) on French river sediments, no match is found from the comparison of trace elements extracted by $0.05 \mathrm{~mol} \cdot \mathrm{L}^{-1}$ EDTA single leaching and by the sums of the reducible and the oxidizable fractions (respectively BCR-F2 + BCR-F3 and LP-F2 + LP-F3). Similarly, no match is found from the comparison between the $0.05 \mathrm{~mol} \cdot \mathrm{L}^{-1}$ EDTA single leaching and the sums of the acido-soluble and the oxidizable fractions (respectively BCRF1 + BCR-F3 and LP-F1 + LP-F3).

Finally, the comparison between the sum of various fractions from SEP and those from single leach procedure give different results, whatever the procedure or the considered element. This observation agrees with the finding of the studies of Leleyter and Baraud (2005) and Leleyter et al. (2012). The procedure of LP-extraction is more efficient than the other three ones for all elements except for $\mathrm{Pb}$.

\subsection{Comparison between the geochemical partitioning of elements determined from both sequential extraction procedures}

In order to investigate the differences found between the total labile fractions of both sequential extraction procedures, a comparison of each extracted non-residual fraction is performed. However, when comparing both sequential extraction procedures, equivalent fractions need to be defined as the BCR comprises three steps compared to seven steps in the LP-extraction (see Table 1):

$\checkmark$ The BCR-F1 fraction is the first step in the BCR procedure and solubilize the acido-soluble fraction. It can be compared to the first three fractions of the LP-extraction, which solubilize the watersoluble fraction (F1a), the exchangeable fraction (F1b) and then the soluble acido fraction (F1c).

$\checkmark$ In the same way, the BCR-F2 fraction, which solubilize the reducible fraction, can be compared to the sum of the three following LPfractions, which solubilize the Mn-oxides (F2a), the amorphous iron oxides fraction (F2b) and the crystalline iron oxides fraction (F2c).

$\checkmark$ The BCR-F3 and LP-F3 fractions can be compared as these two extractions solubilize the oxidable fraction of the sediment or soil.

\subsubsection{Acido-soluble fraction}

The both acido-soluble fractions (BCR-F1) and (LP-F1 $(a+b+c)$ ) are reported in Figs. 2 and 3 and Tables 4 and 5. The standard deviations range from 0 to $4 \%$, depending on the considered element (Tables 4 and 5). It underlines the reproducibility of the acido-soluble step(s) whatever the considered procedure. Three groups of elements are noticed:

$>\mathrm{Al}, \mathrm{Cr}$ and $\mathrm{Fe}$ which are element with no bound with the acidosoluble fraction characterized by the very low F1 extractability $(<3 \%)$.

$>$ elements with similar extracted percentages by the both procedures Mn (22 and 21\%), Ni (11 and 8\%) and Zn (34 and 31\%) respectively for BCR- and LP-F1 fractions.

$>$ elements which are better extracted by the LP-extraction than by the BCR-extraction $\mathrm{Ca}$ (47 and 42\%), $\mathrm{Cu}(25$ and 15\%) and $\mathrm{Pb}(22$ and $2 \%)$ respectively for LP and BCR-F1 extractions.

Generally, the exchangeable step of a sequential extraction procedure is based on the replacement of an exchangeable cation (which is adsorbed onto solid material due to permanent structural charges, so generally located in the interlayer spaces of clay minerals), by another one from a chemical reactant, which has to be a polyvalent cation to optimize this exchange. In the BCR, the cation used in BCR-F1 is the oxonium ion $\left(\mathrm{H}_{3} \mathrm{O}^{+}\right)$, which is a really poor exchangeable cation contrary to the bivalent ions $\mathrm{Mg}^{2+}$, used in the LP-procedure. Thus, it is not surprising that the BCR exchangeable fraction is underestimated. Moreover, in this procedure, the water soluble, the exchangeable and the acido-soluble fractions are extracted in one step with a lower concentration of reagent compared to LP-extraction. The dissolution of the carbonate fraction is probably not complete in BCR, as suggested by the relative decrease of the percentage of $\mathrm{Ca}$ extracted in BCR (42\%) compared to LP-extraction (47\%). Sulkowski and Hirner, (2006) and Dodd et al. (2000) also concluded that the first step of BCR failed to completely leached the carbonate fraction of high carbonate content samples. Then the lower extraction of $\mathrm{Cu}$ and $\mathrm{Pb}$ by BCR-F1 suggest that those elements bound to carbonates, are not leached by this procedure. Alternatively, another assumption would be that the sodium acetate used in the LP-extraction could also remove metals present in forms other than exchangeable or carbonate-bound. Indeed, Hanahan (2004) found that $1 \mathrm{M}$ Na-acetate, $\mathrm{pH} \mathrm{5}$, released metal associated with hydroxide minerals.

\subsubsection{Reducible fraction}

The reducible fractions (BCR-F2 and LP-(F2 $(\mathrm{a}+\mathrm{b}+\mathrm{c}))$ ) determined from the both sequential extractions are reported in Tables 4 and 5 and Figs. 2 and 4. The standards deviation range from 0 to $6 \%$, depending on 


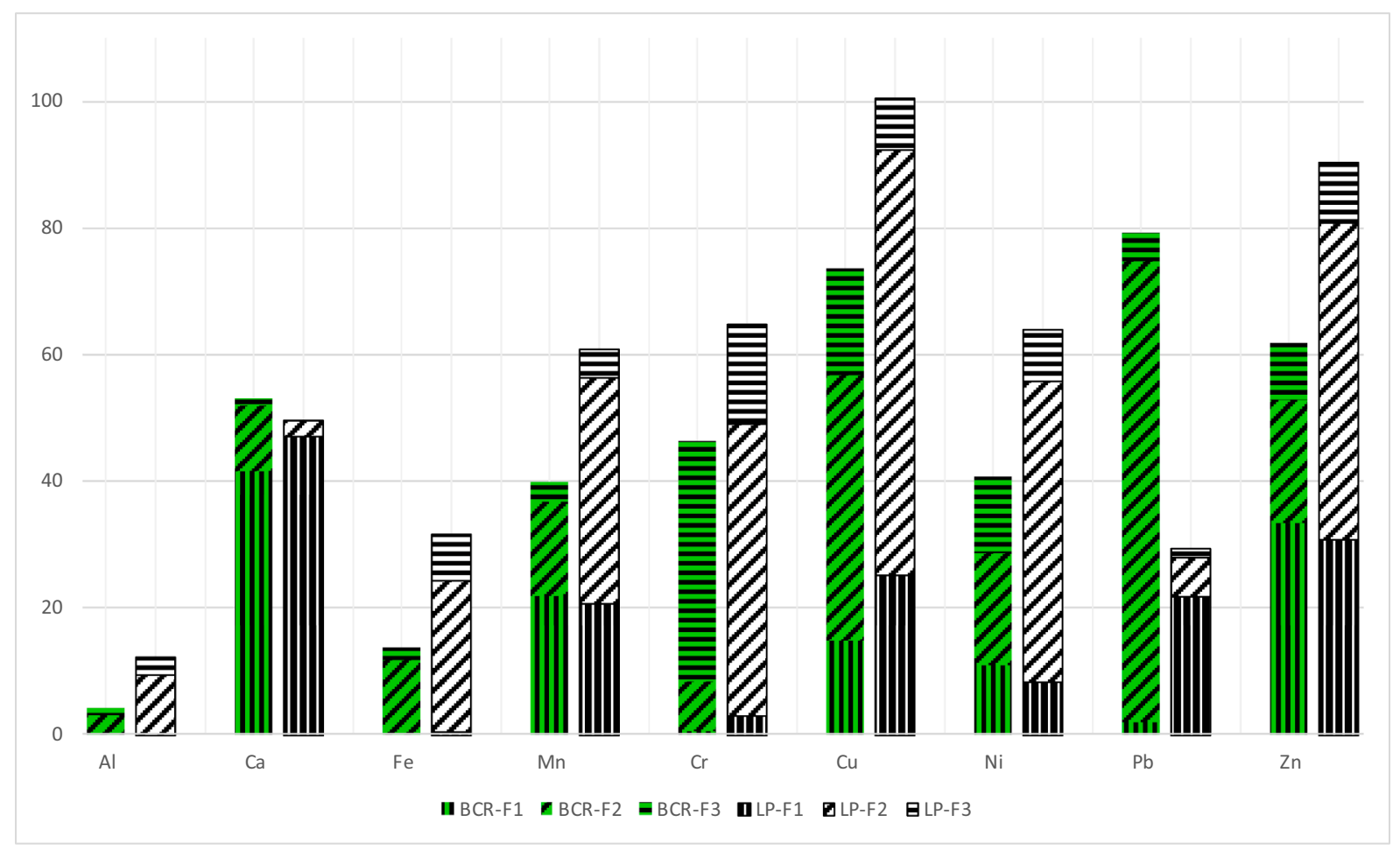

Fig. 2. Percentage of labile metal from sequential BCR (F1 to F3) and LP (F1 to F3) extractions.

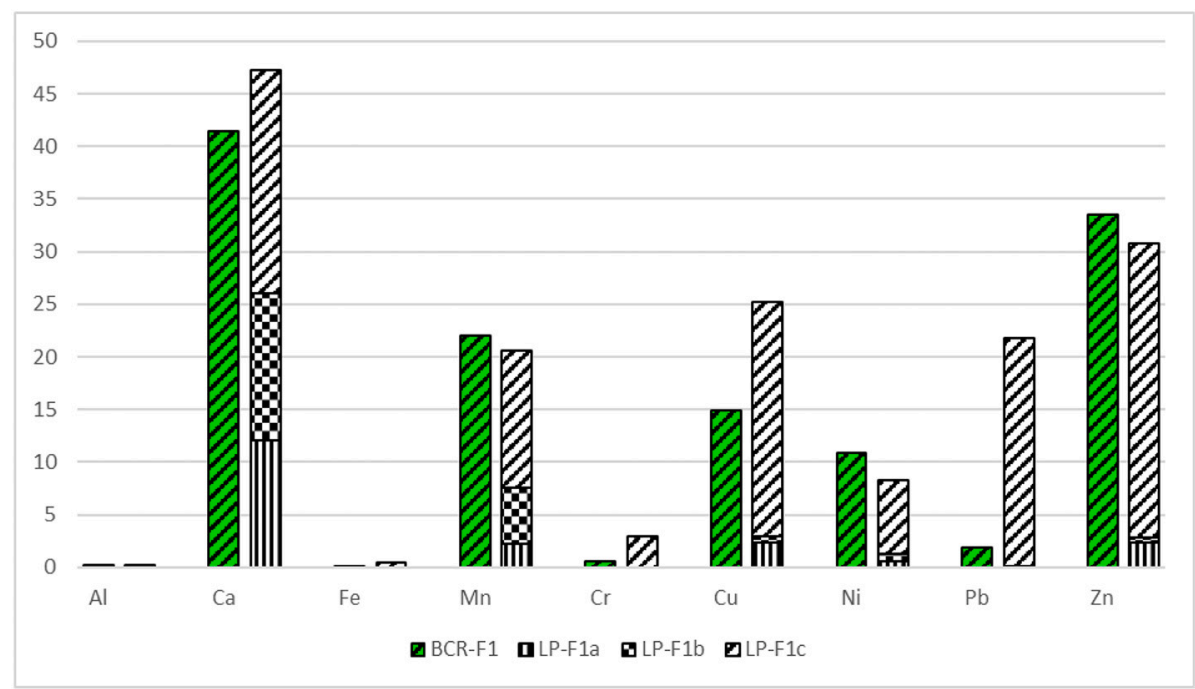

Fig. 3. Percentage of metal bound to acido-soluble fraction from BCR-extraction (BCR-F1) and LP-extraction (LP-F1a: water soluble fraction, LP-F1b: exchangeable fraction, LP-F1c: real acido-soluble fraction).

Table 4

Percentage of labile metal from acido-soluble, reducible and oxydizable fractions from the sequential BCR extraction (F1 to F3). Uncertainties are calculated from the triplicates.

\begin{tabular}{llllllllll}
\hline$\%^{\mathrm{a}}$ & $\mathrm{Al}$ & $\mathrm{Ca}$ & $\mathrm{Fe}$ & $\mathrm{Mn}$ & $\mathrm{Cr}$ & $\mathrm{Cu}$ & $\mathrm{Ni}$ & $\mathrm{Pb}$ & $\mathrm{Zn}$ \\
\hline BCR-F1 & $\mathbf{0 , 2}$ & $\mathbf{4 2}$ & $\mathbf{0 , 1}$ & $\mathbf{2 2}$ & $\mathbf{0 , 5}$ & $\mathbf{1 5}$ & $\mathbf{1 1}$ & $\mathbf{2}$ & $\mathbf{3 4}$ \\
& 0,001 & 0,6 & 0,004 & 0,2 & 0,01 & 1,9 & 0,3 & 0,2 & 0,8 \\
BCR-F2 & $\mathbf{3}$ & $\mathbf{1 1}$ & $\mathbf{1 2}$ & $\mathbf{1 5}$ & $\mathbf{8}$ & $\mathbf{4 2}$ & $\mathbf{1 8}$ & $\mathbf{7 3}$ & $\mathbf{1 9}$ \\
& 0,2 & 0,2 & 0,1 & 0,4 & 0,1 & 3 & 0,3 & 5 & 1 \\
BCR-F3 & $\mathbf{1}$ & $\mathbf{1}$ & $\mathbf{2}$ & $\mathbf{3}$ & $\mathbf{3 8}$ & $\mathbf{1 7}$ & $\mathbf{1 2}$ & $\mathbf{5}$ & $\mathbf{9}$ \\
& 0,1 & 0,03 & 0,1 & 0,1 & 0,9 & 1 & 0,6 & 0,5 & 0,5 \\
\hline
\end{tabular}

${ }^{\text {a }}$ Average in bold and standard deviations in italics.
Table 5

Percentage of labile metal from acido-soluble, reducible and oxydizable fractions from the sequential LP extraction (F1 to F3). Uncertainties are calculated from the triplicates.

\begin{tabular}{llllllllll}
\hline$\%^{\mathrm{a}}$ & $\mathrm{Al}$ & $\mathrm{Ca}$ & $\mathrm{Fe}$ & $\mathrm{Mn}$ & $\mathrm{Cr}$ & $\mathrm{Cu}$ & $\mathrm{Ni}$ & $\mathrm{Pb}$ & $\mathrm{Zn}$ \\
\hline LP-F1 & $\mathbf{0 , 2}$ & $\mathbf{4 7}$ & $\mathbf{1}$ & $\mathbf{2 1}$ & $\mathbf{3}$ & $\mathbf{2 5}$ & $\mathbf{8}$ & $\mathbf{2 2}$ & $\mathbf{3 1}$ \\
& 0,01 & 4 & 0,0 & 3 & 0,1 & 1 & 0,5 & 1 & 1 \\
LP-F2 & $\mathbf{9}$ & $\mathbf{2}$ & $\mathbf{2 4}$ & $\mathbf{3 6}$ & $\mathbf{4 6}$ & $\mathbf{6 7}$ & $\mathbf{4 7}$ & $\mathbf{6}$ & $\mathbf{5 0}$ \\
& 1 & 0,2 & 2 & 3 & 5 & 6 & 4 & 2 & 4 \\
LP-F3 & $\mathbf{3}$ & $<\mathrm{LD}$ & $\mathbf{7}$ & $\mathbf{4}$ & $\mathbf{1 6}$ & $\mathbf{8}$ & $\mathbf{8}$ & $\mathbf{1}$ & $\mathbf{1 0}$ \\
& 0,3 & & 0,2 & 0,4 & 1 & 0,8 & 0,5 & 0,5 & 0,5 \\
\hline
\end{tabular}

${ }^{\text {a }}$ Average in bold and standard deviations in italics. 


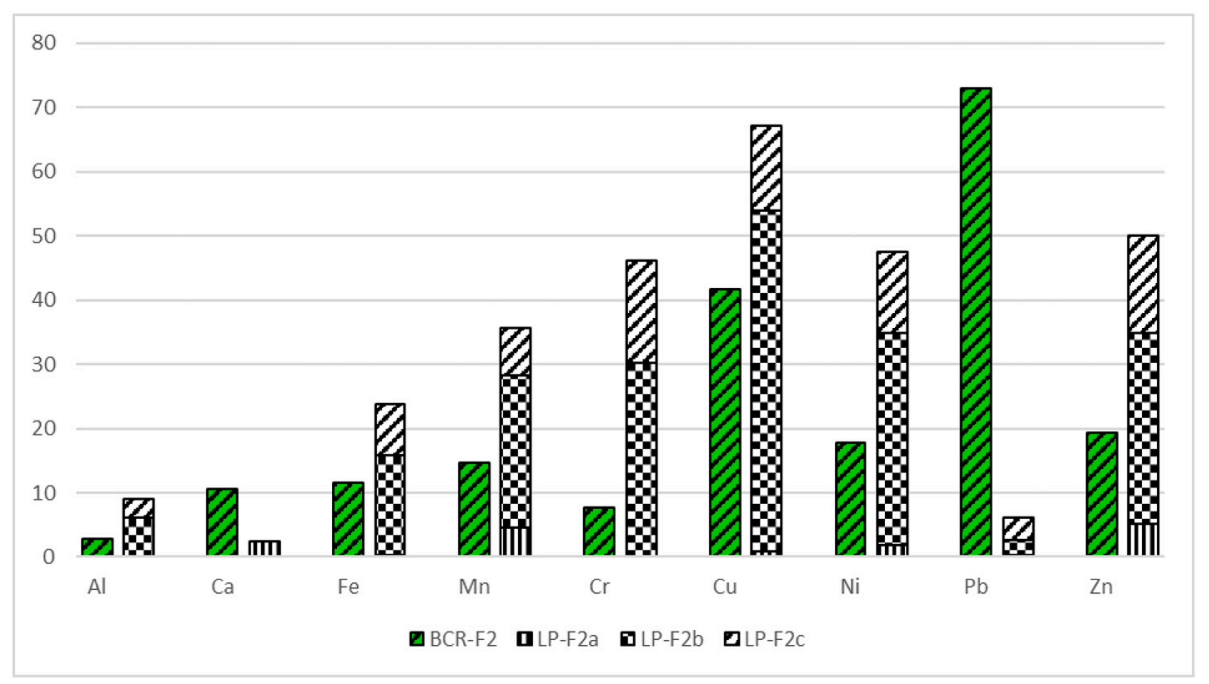

Fig. 4. Percentage of metal bound to reducible fraction from BCR-extraction (BCR-F2) and LP-extraction (LP-F2a: bound to manganese oxides, LP-F2b: bound to amorphous iron oxides, LP-F2c: bound to crystalline iron oxides).

the considered element (Tables 4 and 5). It underlines the reproducibility of the reducible step(s) whatever the considered procedures.

The percentages extracted by the LP-extraction are, on average, 2 to 6 times higher than those from the BCR-procedure, for all elements, except for $\mathrm{Ca}$ and $\mathrm{Pb}$. The LP-F2 percentage of $\mathrm{Fe}$ and $\mathrm{Mn}$ extracted are respectively 24 and 36\% and are significantly higher compared to 12 and $15 \%$ extracted by F2-BCR. This result (agreed with Anju and Banerjee, 2010 and Caraballo et al., 2018) suggests a lower efficiency of the BCR-procedure in the dissolution of Mn- and Fe-oxides.

The sum of Fe and Mn extracted at the Mn-oxides (F2a) and the amorphous Fe-oxides (F2b) fraction in the LP-extraction are 16 and $28 \%$, respectively. The percentage of amorphous Fe extracted is comparable to that obtained from the BCR, but a lower dissolution of the Mnoxides is highlighted. We can conclude that BCR-procedure is not able to solubilize neither the totality of the manganese oxides (the quantity of solubilized manganese is even less important than that mineralized after EDTA-extraction) nor the crystalline iron oxides. The infective dissolution of iron oxides was already observed when applying BCR-extraction procedure (Leermakers et al., 2019). These results can be explained by the fact that the reducible step from BCR is realized at the room temperature. Crystalline Fe-oxides are only poorly (or not) dissolved, even considering the low $\mathrm{pH}$ of this step. Moreover, hydroxylammonium is known to be a powerful reducing agent, a perfect reagent to reduce insoluble $\mathrm{Mn}^{\mathrm{IV}}$ to soluble $\mathrm{Mn}^{2+}$, but this reagent is not efficient enough to mineralize iron oxides, like goethite (1) or hematite (2), characterized by a lower standard potential (respectively $\mathrm{E}^{\circ}=0.92$ and $0.86 \mathrm{~V} / \mathrm{ENH}$ ).

Leleyter and Probst (1999) measured the percentage of leached $\mathrm{Fe}$ during an oxide leaching procedure $\left(\mathrm{NH}_{2} \mathrm{OH} \cdot \mathrm{HCl} 0.1 \mathrm{M}, \mathrm{pH}=3.5,30\right.$ $\mathrm{min}$ ) performed on four different iron oxides: a synthetic hematite black powder from Schering A.G. Berlin, a natural goethite ochre powder from Atlantis II, carrot 1032 VIII 1-6, a natural mix hematite and goethite orange powder from Atlantis II, carrot 1032 XI 75-80 and a synthetic hematite red powder from Merck. For all these oxides, the percentage is equal to zero, confirming the low efficiency of this reagent to dissolve Fe-oxides. However, the reducing power of this reactant can be enhanced in more extreme conditions, such as heating or low $\mathrm{pH}$. However such conditions provoke the partial dissolution of clay minerals (Robbins et al., 1982) then a potential overestimation of the extracted percentages for the reducible fraction.

Thus, the high percentages of $\mathrm{Cr}, \mathrm{Cu}, \mathrm{Ni}$ and $\mathrm{Zn}$ extracted at the reducible step of LP-extraction can be probably explained by the combination of the reactants used and by the division of the reducible fraction into three distinct steps, allowing the increase of the dissolution efficiency of amorphous and crystalline oxides. Indeed, Leleyter and Probst (1999) found that the leached Fe percentage by the reducible step of LP-extraction extracted from 73 to $97 \%$ of the synthetic iron oxides. Additionally, Davidson et al. (2004) found that the substitution of the hydroxylammonium chloride by ammonium oxalate at the step 2 of the BCR step allowed an increase of the extracted Fe- and $\mathrm{Cu}-$ and also $\mathrm{Zn}$ contents. It was explained by the ability of ammonium oxalate to liberate iron and related elements from mineralogical phases which would be classed, under the BCR scheme, as part of the residual fraction. On the contrary, the BCR probably leads to an underestimation of elements associated with the reducible phase and a potential overestimation of the residue.

Contrary to the others elements, $\mathrm{Ca}$ and $\mathrm{Pb}$ are better extracted in the reducible fraction of BCR than LP-extraction. As all the labile fractions, BCR-F $F_{\text {lab }}$, LP-F lab $_{\text {laCl }} \mathrm{F}_{\text {lab }}$ and EDTA-F $\mathrm{F}_{\text {lab }}$ give quite similar results for calcium extraction (53, 50, 50 and $49 \%$ respectively), it can be assumed that a better calcium extraction during the 3 steps of the LP-F1 (than BCR-F1), explains a lower extraction of calcium during LP-F2. On the contrary, the BCR extracted over $40 \%$ of lead compared with the LPextraction, but also compared with both single leaching procedures ( $\mathrm{HCl}$ and EDTA). The particular case of lead will be discussed further in this study.

\subsubsection{Oxidizable fraction}

The percentages extracted by the both procedures (BCR-F3 compared to LP-F3) are given in Tables 4 and 5 and Fig. 2. The standards deviation ranges from 0,03 to $1 \%$, which underlines once again the reproducibility of the oxidizable step. The percentages of $\mathrm{Cr}, \mathrm{Cu}, \mathrm{Ni}$ and $\mathrm{Pb}$, leached from the oxidizable phase, are significantly higher in the BCR than in the LP-extraction.

Sahuquillo et al. (2003) highlighted a decrease of the oxidizable fraction of the reference material CRM-601 between the first (from Quevauviller et al., 1994) and the modified (from Rauret et al., 1999) standardized sequential procedure, for $\mathrm{Cr}, \mathrm{Cu}, \mathrm{Pb}$ and into a lesser extent, Ni. Indeed, in the modified procedure, the decrease of the oxidizable fraction is associated with an increase of the reducible one, involving two assumptions. The first one is the decrease of the readsorption phenomena in the reducible step, previously occurring in the procedure from Quevauviller et al. (1994). These re-adsorption phenomena would lead to an overestimation of the oxidizable fraction of this procedure. Conversely, the second assumption is the increase of the specificity of the extraction in the BCR, thus limiting the subsequent dissolution of the Fe-oxides in the oxidizable phase of the procedure 
from Quevauviller et al. (1994). Following this assumption, this fraction was previously only partially digested during the reducible step.

A similar trend was observed in the present study, i.e. an increase of the reducible fraction in the LP-extraction associated with a decrease of the oxidizable one, compared to the BCR, for the same elements. As an example, the extracted percentage of $\mathrm{Cr}$ and $\mathrm{Cu}$ of the reducible fraction are $46 \%$ and $67 \%$ then $8 \%$ and $42 \%$, in the LP-extraction then BCR respectively. On the contrary, the values are $16 \%$ and $8 \%$ then $38 \%$ and $17 \%$ in the oxidizable fraction for the LP then BCR-extractions respectively. Assuming that the low $\mathrm{pH}$ (1.5) of the reducible fraction of the BCR prevent re-adsorption processes involving further overestimation of the following step, one explanation could be that the Fe-oxides, only partially dissolved in the reducible step of the BCR, are further dissolved in the oxidizable one. The comparison between the sum of the oxidizable and the reducible fractions of both procedures are similar and thus let us confident with this assumption (Fig. 2).

Alternatively, the increase of the extracted percentage of $\mathrm{Cu}$ during the reducible fraction of the LP-extraction could be due to an overestimation of the reducible fraction. Indeed, copper oxalate complex formation is relatively easy. Thus, these complexes could remove copper from the oxidizable phases (Slavek and Pickering, 1986; Benitez and Dubois, 1999; Davidson et al., 2004). Other assumptions could involve (1) re-adsorption phenomena occurring in the oxidizable step of the LPextraction, (2) a lower ability of this procedure to extract the elements located in this fraction, according to Fernández Alborés et al. (2000), or (3) a premature extraction of organically-bound metals from the exchangeable fraction, as found by Gómez-Ariza et al. (2000) for the four step Tessier procedure (Tessier et al., 1979). This third hypothesis could be supported by the higher percentage of $\mathrm{Cu}$ in the LP-F1 (25\%) compared to the BCR-F1 (15\%).

\subsection{Contribution of single and sequential leaching procedures on the understanding of labile $\mathrm{Pb}$ behavior}

Contrary to the other elements, lead shows a preferential extraction by the BCR (Fig. 1). Thus, lead re-adsorption and/or co-precipitation phenomena might occurred in the other procedures. Davidson et al. (2004) used $0.2 \mathrm{~mol} \cdot \mathrm{L}^{-1}$ of ammonium oxalate instead of $0.5 \mathrm{~mol} \cdot \mathrm{L}^{-1}$ hydroxylammonium hydrochloride, for an identical $\mathrm{pH}$ value of 1.5 . It decreased the proportions of $\mathrm{Ca}$ and $\mathrm{Pb}$ released, for the reducible step performed on the certified lake sediment CRM-601. According to these authors, a rapid precipitation of analytes oxalates from the solution is the most likely assumption explaining the decrease found in the LPextraction. Additionally, Sahuquillo et al. (1999) also found that the replacement of hydroxylammonium chloride by ammonium hydrogen oxalate and oxalic acid induced the precipitation of insoluble $\mathrm{Pb}$ salts, in particular in the presence of $\mathrm{Ca}$ (due to co-precipitation phenomenon). Thus, similar explanation could be expected in our study. The relatively low solubility of $\mathrm{Pb}$ oxalate $\left(\mathrm{Ks}=1.7 * 10^{-5}\right.$ ) and the high amount of lead present in the extract, as deduced from the BCR procedure, could induce the precipitation of lead oxalate from solution (Pickering, 1986; Benitez and Dubois, 1999; Gleyzes et al., 2002; Davidson et al., 2004). It is consistent with the fact that no $\mathrm{Ca}$ is found in the extracts corresponding to the oxalate steps, i.e. LP-F2b and LP-F2c (see Fig. 4).

The total labile fraction of $\mathrm{Pb}$ is also higher in the BCR than in both single leach procedures. In the case of $0.5 \mathrm{~mol} \cdot \mathrm{L}^{-1} \mathrm{HCl}$, the low percentage of $\mathrm{Pb}$ extracted could be explained by the $\mathrm{Pb}$ re-adsorption and re-distribution processes. Indeed, $\mathrm{PbCl}_{2}$ precipitation phenomenon (Ks $=1.8 * 10^{-3}$ ) were already observed by Wei et al. (2005), by XAS analysis. They reported that, during a $0.1 \mathrm{~mol} \cdot \mathrm{L}^{-1} \mathrm{HCl}$ extraction, the main part of lead is converted into precipitated $\mathrm{PbCl}_{2}$. They concluded that estimating the level of metals uptake by plant material using 0.1 $\mathrm{mol} \cdot \mathrm{L}^{-1} \mathrm{HCl}$, can underestimate $\mathrm{Pb}$ uptake because lead cations readily reacted with chloride to form $\mathrm{PbCl}_{2}$ precipitates that are only poorly soluble in dilute acid or water. In the case of $0.05 \mathrm{~mol} \cdot \mathrm{L}^{-1}$ EDTA leach procedure, Kim et al. (2003) found that major cations like Fe and trace elements like $\mathrm{Cu}$ and $\mathrm{Zn}$ potentially compete with lead for EDTA ligand sites. Moreover, according to this study, the occlusion of $\mathrm{Pb}$ on Fe oxides and the type of $\mathrm{Pb}$ species can affect the $\mathrm{Pb}$ extraction efficiency. On the contrary, Leleyter et al. (2012) assumed that $0.05 \mathrm{~mol} \cdot \mathrm{L}^{-1}$ EDTA extraction was the best suited method to estimate the $\mathrm{Pb}$ mobility, compared to $\mathrm{HCl}$ and LP-extraction for various soils and sediments.

Alternatively, the better extraction of $\mathrm{Pb}$ by the reducible step of $\mathrm{BCR}$ could be explained by the specific physico-chemical parameters of its reducible step. The increase of the concentration of the hydroxylammonium hydrochloride, from $0.1 \mathrm{~mol} \cdot \mathrm{L}^{-1}$ (in the original standardized BCR procedure) to $0.5 \mathrm{~mol} \cdot \mathrm{L}^{-1}$ (in the modified one), leaded to an increase up to $30 \%$ of the percentage of $\mathrm{Pb}$ extracted (Rauret et al., 1999; Sahuquillo et al., 2003). On the contrary, the concentration of the reactants used in the different steps of the reducible fraction of the LPextraction is $0.2 \mathrm{~mol} \cdot \mathrm{L}^{-1}$ only. Moreover, the $\mathrm{pH}$ value of the reducible step is 1.5 for the BCR and 3.5 to 2.3 for the LP-extraction; this lower $\mathrm{pH}$ could also explain better extractability of $\mathrm{Pb}$ by BCR, as suggested by Sahuquillo et al. (1999), since the extractability of lead is sensitive to a decrease of $\mathrm{pH}$.

\section{Conclusions}

The aim of this study was to compare the potential availability and the partitioning of $\mathrm{Cr}, \mathrm{Cu}, \mathrm{Zn}, \mathrm{Ni}$ and $\mathrm{Pb}$ between four leaching procedures commonly found in the literature, i.e. two single $\left(0.5 \mathrm{~mol} \cdot \mathrm{L}^{-1}\right.$ $\mathrm{HCl}$ and $0.05 \mathrm{~mol} \cdot \mathrm{L}^{-1} \mathrm{EDTA}$ ) and two sequential (from Rauret et al., 1999 and from Leleyter and Probst, 1999) extractions. The procedures were all performed on the reference lake sediment BCR-701, commonly used to assess the accuracy of the modified standardized procedure of Rauret et al. (1999). Major elements like Al, Ca, Fe and Mn were also studied in order to investigate the selectivity of the four used procedures.

Similar percentages of $\mathrm{Cr}, \mathrm{Cu}, \mathrm{Pb}$ and $\mathrm{Zn}$ are extracted by both single leach procedures, but the dissolved phases are probably not the same, as suggested by the difference between the percentages of $\mathrm{Al}$ and $\mathrm{Mn}$ extracted. Thus, $0.5 \mathrm{~mol} \cdot \mathrm{L}^{-1} \mathrm{HCl}$ could be more efficient than 0.05 $\mathrm{mol} \cdot \mathrm{L}^{-1}$ EDTA to remove trace elements from the reducible phase. The comparison between the single leaching procedures and the sum of various steps of the two sequential extraction procedures indicate that all the operationally defined fractions are impacted by dilute $\mathrm{HCl}$ and $0.05 \mathrm{~mol} \cdot \mathrm{L}^{-1}$ EDTA extractions. Thus, it is difficult to associate the amount of trace elements extracted by one or the other single reactant, to one particular mineralogical fraction. As a whole, the LP-extraction appears more extractive and efficient than the standardized BCR procedure for all elements (excepted lead) probably due to a better extraction of the exchangeable fraction, to a better dissolution of the acido-soluble phase and a better dissolution of the amorphous and crystalline Fe-oxides.

On the contrary, BCR-extraction is more efficient to extract $\mathrm{Pb}$ (i.e. $80 \%$ ) compared to the others three procedures, that show similar amount of extracted $\mathrm{Pb}$ (ranging from 24 to $29 \%$ ). Two assumptions could be proposed. The first one involves co-precipitation and/or lowextraction processes occurring in the three others procedures. The second one involves the particular physico-chemical properties of the reducible phase of $\mathrm{BCR}$ (i.e. low $\mathrm{pH}$ and strong reactant concentration). These conditions could induce an extraction of $\mathrm{Pb}$ previously retained in the residual phase, and thus an overestimation of the real $\mathrm{Pb}$ availability.

Finally, $\mathrm{Ca}$ and, in a lesser extent $\mathrm{Cr}$, are the only elements showing close availabilities by the four procedures. LP-extraction seems the more suitable method to estimate the potential availability of $\mathrm{Cu}, \mathrm{Ni}$ and $\mathrm{Zn}$ whereas BCR could be more adapted to estimate the $\mathrm{Pb}$ availability. However, the choice of the procedure and of the reactants must be previously deduced from the physico-chemical properties of the sample and the aim of the study. A mineralogical characterization of the residual phase could help to understand if co-precipitation phenomena have occurred in the procedure of Leleyter and Probst (1999) or during 
the $0.5 \mathrm{~mol} \cdot \mathrm{L}^{-1} \mathrm{HCl}$ single leach, explaining the difference of the $\mathrm{Pb}$ labile fractions between the procedures.

\section{Declaration of competing interest}

The authors certify that they have no affiliations with or involvement in any organization or entity with any financial interest (such as honoraria; educational grants; participation in speakers' bureaus; membership, employment, consultancies, stock ownership, or other equity interest; and expert testimony or patent-licensing arrangements), or non-financial interest (such as personal or professional relationships, affiliations, knowledge or beliefs) in the subject matter or materials discussed in this manuscript.

\section{Acknowledgements}

The authors would like to thank the technicians and engineers of the different analytical platforms used for this work (clean rooms, ICP-OES and ICP-MS at Observatoire Midi Pyrénées). This research was funded by a PhD grant to Alicia Cuvier from the Région Midi-Pyrénées and IRSN hosted at Toulouse INP.

\section{References}

Agemian, H., Chau, A.S.Y., 1976. Evaluation of extraction techniques for the determination of metals in aquatic sediments. Analyst 101, 761-767.

Alan, M., Kara, D., 2019. Comparison of a new sequential extraction method and the BCR sequential extraction method for mobility assessment of elements around boron mines in Turkey. Talanta 189-198.

Anju, M., Banerjee, D.K., 2010. Comparison of two sequential extraction procedures for heavy metal partitioning in mine tailings. Chemosphere 78, 1393-1402.

Aubert, D., Probst, A., Stille, P., 2004. Distribution and origin of major and trace elements (particularly REE, $\mathrm{U}$ and Th) into labile and residual phases in an acid soil profile (Vosges Mountains, France). Appl. Geochem. 19 (6), 899-916. https://doi. org/10.1016/j.apgeochem.2003.11.005.

Avumadi, A., Gnandi, K., Probst, J.L., 2019. Trace element distribution and enrichment in the stream sediments of the Lake Togo watersheds (south of Togo). Adv. Ecol. Environ. Res. 87-114 (ISSN 2517-9454).

Baize, D., 1997. Teneurs totales en éléments traces métalliques dans les sols (France), Editions Quae.

Baraud, F., Leleyter, L., Lemoine, M., Hamdoun, H., 2017. Cr in dredged marine sediments: anthropogenic enrichment, bioavailability and potential adverse effects. Mar. Pollut. Bull. 120, 303-308.

Baudo, R., Amantini, L., Cenci, F., Bo, R., Hannaert, P., Lattanzio, A., Marengo, G. Muntau, H., 1989. Spatial distribution patterns of metals in the surface sediments of Lake Orta (Italy). Sci. Total Environ. 87-88, 117-128.

Benabdelkader, A., Taleb, A., Probst, J.L., Belaidi, N., Probst, A., 2019. Origin, distribution, and behaviour of rare earth elements in river bed sediments from a carbonate semi-arid basin (Tafna River, Algeria). Appl. Geochem. 106, 96-111.

Benitez, L.-N., Dubois, J.-P., 1999. Evaluation of ammonium oxalate for fractionating metallic trace elements in soils by sequential extraction. Int. J. Environ. Anal. Chem. 75 (3), 261-273. https://doi.org/10.1080/03067319908047315.

Bur, T., Probst, J.L., N'guessan, M., Probst, A., 2009. Distribution and origin of lead in stream sediments from small agricultural catchments draining miocene molassic deposits (SW France). Appl. Geochem. 24 (7), 1324-1338. https://doi.org/10.1016/ j.apgeochem.2009.04.004.

Camizuli, E., Monna, F., Bermond, A., Manouchehri, N., Besançon, S., Losno, R., van Oort, F., Labanowski, J., Perreira, A., Chateau, C., Alibert, P., 2014. Impact of historical mining assessed in soils by kinetic extraction and lead isotopic ratios. Sci. Total Environ. 472, 425-436. https://doi.org/10.1016/j.scitotenv.2013.10.103.

Caraballo, M.A., Serna, A., Macías, F., Pérez-López, R., Ruiz-Cánovas, C., Richter, P., Becerra-Herrera, M., 2018. Uncertainty in the measurement of toxic metals mobility in mining/mineral wastes by standardized BCR®SEP. J. Hazard. Mater. 360, 587-593.

Cecchi, M., Dumat, C., Alric, A., Felix-Faure, B., Pradere, P., Guiresse, M., 2008. Multimetal contamination of a calcic cambisol by fallout from a lead-recycling plant. Geoderma Antarctic Soils Soil Form. Process. Chang. Environ. 144 (1-2), 287-298. https://doi.org/10.1016/j.geoderma.2007.11.023.

Chao, T.T., 1984. Use of partial dissolution techniques in geochemical exploration. J. Geochem. Explor. 20 (2), 101-135. https://doi.org/10.1016/0375-6742(84) 90078-5.

Da Silva, I.S., Abate, G., Lichtig, J., Masini, J.C., 2002. Heavy metal distribution in recent sediments of the tietê-pinheiros river system in São Paulo State, Brazil. Appl. Geochem. 17 (2), 105-116. https://doi.org/10.1016/S0883-2927(01)00086-5.

Davidson, C.M., Duncan, A.L., Littlejohn, D., Ure, A.M., Garden, L.M., 1998. A critical evaluation of the three-stage BCR sequential extraction procedure to assess the potential mobility and toxicity of heavy metals in industrially-contaminated land. Anal. Chim. Acta 363 (1), 45-55.
Davidson, C.M., Hursthouse, A.S., Tognarelli, D.M., Ure, A.M., Urquhart, G.J., 2004. Should acid ammonium oxalate replace hydroxylammonium chloride in step 2 of the revised BCR sequential extraction protocol for soil and sediment? Anal. Chim. Acta 508 (2), 193-199. https://doi.org/10.1016/j.aca.2003.11.076.

Dodd, J., Large, D.J., Fortey, N.J., Milodowski, A.E., Kemp, S., 2000. A petrographic investigation of two sequential extraction techniques applied to anaerobic canal bed mud. Environ. Geochem. Health 22 (4), 281-296.

El Azzi, D., Viers, J., Guiresse, M., Probst, A., Aubert, D., Caparros, J., Charles, F., Guizien, K., Probst, J.L., 2013. Origin and fate of copper in a small mediterranean vineyard catchment: new insights from combined chemical extraction and $865 \mathrm{Cu}$ isotopic composition. Sci. Total Environ. 463-464 (October), 91-101. https://doi. org/10.1016/j.scitotenv. 2013.05.058.

El-Azim, A.H., El-Moselhy, Kh.M., 2005. Determination and partitioning of metals in sediments along the Suez Canal by sequential extraction. J. Mar. Syst. 56 (3-4), 363-374. https://doi.org/10.1016/j.jmarsys.2004.12.001.

Fernández Alborés, A., Pérez Cid, B., Fernández Gómez, E., Falqué López, E., 2000. Comparison between sequential extraction procedures and single extractions for metal partitioning in sewage sludge samples. Analyst 125 (7), 1353-1357. https:// doi.org/10.1039/B001983F.

Filgueiras, A.V., Lavilla, I., Bendicho, C., 2002. Chemical sequential extraction for metal partitioning in environmental solid samples. J. Environ. Monit. 4, 823-857.

Fu, C., Tu, C., Zhang, H., Li, Y., Li, L., Zhou, Q., Scheckel, K.G., Luo, Y., 2020. Soil accumulation and chemical fractions of $\mathrm{Cu}$ in a large and long-term coastal apple orchard, North China. J. Soils Sediments 20, 3712-3721.

Gabelle, C., Baraud, F., Biree, L., Gouali, S., Hamdoun, H., Rousseau, C., van Veen, E., Leleyter, L., 2012. The impact of aluminium sacrificial anodes on the marine environment: a case study. Appl. Geochem. 27 (10), 2088-2095. https://doi.org/ 10.1016/j.apgeochem.2012.07.001.

Gaiero, D.M., Probst, J.-L., Depetris, P.J., Bidart, S.M., Leleyter, L., 2003. Iron and other transition metals in patagonian riverborne and windborne materials: geochemical control and transport to the Southern South Atlantic Ocean. Geochim. Cosmochim. Acta 67 (19), 3603-3623. https://doi.org/10.1016/S0016-7037(03)00211-4.

Giancoli Barreto, S., Nozaki, J., De Oliveira, E., Do Nascimento Filho, V.F., Aragão, P.H., Scarminio, I.S., Barreto, W.J., 2004. Comparison of metal analysis in sediments using EDXRF and ICP-OES with the $\mathrm{HCl}$ and Tessie extraction methods. Talanta 64 (2), 345-354. https://doi.org/10.1016/j.talanta.2004.02.022.

Gil-Díaz, M., Luchsinger-Heitmann, A., García-Gonzalo, P., Alonso, J., Lobo, M.C., 2021. Selecting efficient methodologies for estimation of $\mathrm{As}$ and $\mathrm{Hg}$ availability in a brownfield. Environ. Pollut. 270, 116-290.

Gismera, M.J., Lacal, J., da Silva, P., García, R., Sevilla, M.T., Procopio, J.R., 2004. Study of metal fractionation in river sediments. A comparison between kinetic and sequential extraction procedures. Environ. Pollut. 127 (2), 175-182. https://doi. org/10.1016/j.envpol.2003.08.004.

Gleyzes, C., Tellier, S., Astruc, M., 2002. Fractionation studies of trace elements in contaminated soils and sediments: a review of sequential extraction procedures. TrAC Trends Anal. Chem. 21 (6), 451-467.

Gómez-Ariza, J.L., Giraldez, I., Sanchez-Rodas, D., Morales, E., 2000. Selectivity assessment of a sequential extraction procedure for metal mobility characterization using model phases. Talanta 52 (3), 545-554.

Hamdoun, H., Van-Veen, E., Basset, B., Lemoine, M., Coggan, J., Leleyter, L., Baraud, F., 2015a. Characterization of harbor sediments from the English channel: assessment of heavy metal enrichment, biological effect and mobility. Mar. Pollut. Bull. 90 (1-2), 273-280. https://doi.org/10.1016/j.marpolbul.2014.10.030.

Hamdoun, H., Leleyter, L., Van-Veen, E., Basset, B., Lemoine, M., Baraud, F., 2015b. Comparison of three procedures (single, sequential and kinetic extraction) for mobility assessment of $\mathrm{Cu}, \mathrm{Pb}$ and $\mathrm{Zn}$ from harbour sediments. CRAS-Géosci. 347, 94-102.

Han, Hyeop-Jo, Lee, Jong-Un, Ko, Myoung-Soo, Kim, Kyoung-Woong, 2020. Comparison of five extraction methods for evaluating cadmium and zinc immobilization in soil. Environ. Geochem. Health 42, 4203-4212.

Hanahan, C., 2004. Dissolution of hydroxide minerals in the $1 \mathrm{M}$ sodium acetate, pH 5, extracting solution in sequential extraction schemes. Environ. Geol. 45 (6), 864-868. https://doi.org/10.1007/s00254-003-0946-3.

Juste, C., 1989. Mobilité et Biodisponibilité Des Oligo-éléments. In: Les Oligo-éléments et Le Sol, 2e Journées de L'analyse de Terre, Frontières. GEMAS, pp. 5-15.

Khelifi, F., Melki, A., Hamed, Y., Adamo, P., Caporale, A.G., 2020. Environmental and human health risk assessment of potentially toxic elements in soil, sediments, and oreprocessing wastes from a mining area of southwestern Tunisia. Environ. Geochem. Health 42, 4125-4139.

Kim, C., Lee, Y., Ong, S.K., 2003. Factors affecting EDTA extraction of lead from leadcontaminated soils. Chemosphere 51 (9), 845-853. https://doi.org/10.1016/S00456535(03)00155-3.

Kubová, J., Streško, V., Bujdoš, M., Matúš, P., Medved, J., 2004. Fractionation of various elements in CRMs and in polluted soils. Anal. Bioanal. Chem. 379 (1), 108-114. https://doi.org/10.1007/s00216-004-2505-5.

Kubová, J., Matúš, P., Bujdoš, M., Hagarová, I., Medved, J., 2008. Utilization of optimized BCR three-step sequential and dilute $\mathrm{HCl}$ single extraction procedures for soil-plant metal transfer predictions in contaminated lands. Talanta 75 (4), 1110-1122. https://doi.org/10.1016/j.talanta.2008.01.002.

Kumkrong, P., Mihai, O., Mercier, P.H.J., Pihilligawa, I.G., Tyo, D.D., Mester, Z., 2020. Tessier sequential extraction on 17 elements from three marine sediment certified reference materials (HISS-1, MESS-4, and PACS-3). Anal. Bioanal. Chem. https://doi. org/10.1007/s00216-020-03063-Z.

Kuo, S., Lai, M.S., Lin, C.W., 2006. Influence of solution acidity and $\mathrm{CaCl} 2$ concentration on the removal of heavy metals from metal-contaminated rice soils. Environ. Pollut. 144 (3), 918-925. https://doi.org/10.1016/j.envpol.2006.02.001. 
Leermakers, M., Mbachou, B.E., Husson, A., Lagneau, V., Descostes, M., 2019. An alternative sequential extraction scheme for the determination of trace elements in ferrihydrite rich sediments. Talanta 80-88.

Leleyter, L., 2017. Sols et sédiments pollués: Teneurs élémentaires totales et biodisponibles, 61p, Editor. Editions Européennes Universitaires (ISBN: 978-3-33087630-9).

Leleyter, L., Baraud, F., 2005. Évaluation de la mobilité des métaux dans les sédiments fluviaux du bassin de la Vire (Normandie, France) par extractions simples ou séquentielles. Compt. Rendus Geosci. 337 (6), 571-579. https://doi.org/10.1016/j crte.2005.01.001.

Leleyter, L., Baraud, F., 2006. Selectivity and efficiency of the acido-soluble extraction in sequential extraction procedure. Int. J. Soil Sci. 1 (2), 168-170.

Leleyter, L., Probst, J.L., 1999. A new sequential extraction procedure for the speciation of particulate trace elements in river sediments. Int. J. Environ. Anal. Chem. 73 (2), $109-128$.

Leleyter, L., Rousseau, C., Biree, L., Baraud, F., 2012. Comparison of EDTA, $\mathrm{HCl}$ and sequential extraction procedures, for selected metals $(\mathrm{Cu}, \mathrm{Mn}, \mathrm{Pb}, \mathrm{Zn})$, in soils, riverine and marine sediments. J. Geochem. Explor. 116-117 (May), 51-59. https:// doi.org/10.1016/j.gexplo.2012.03.006.

Leleyter, L., Baraud, F., Reinert, T., Gouali, S., Lemoine, M., Gil, O., 2018. 2018, Fate of aluminium released by sacrificial anodes - contamination of marine sediments by environmentally available compounds. C. R. Geosci. 350, 195-201.

Madrid, F., Reinoso, R., Florido, M.C., Díaz Barrientos, E., Ajmone-Marsan, F., Davidson, C.M., Madrid, L., 2007. Estimating the extractability of potentially toxic metals in urban soils: a comparison of several extracting solutions. Environ. Pollut 147 (3), 713-722. https://doi.org/10.1016/j.envpol.2006.09.005.

McCready, S., Birch, G.F., Taylor, S.E., 2003. Extraction of heavy metals in Sydney harbour sediments using $1 \mathrm{M} \mathrm{HCl}$ and $0.05 \mathrm{M}$ EDTA and implications for sedimentquality guidelines. Aust. J. Earth Sci. 50 (2), 249-255. https://doi.org/10.1046/ j.1440-0952.2003.00994.x.

Menzies, N.W., Donn, M.J., Kopittke, P.M., 2007. Evaluation of extractants for estimation of the phytoavailable trace metals in soils. Environ. Pollut. 145 (1), 121-130. https://doi.org/10.1016/j.envpol.2006.03.021.

Naz, A., Chowdhury, A., Chandra, R., Mishra, B.K., 2020. Potential human health hazard due to bioavailable heavy metal exposure via consumption of plants with ethnobotanical usage at the largest chromite mine of India. Environ. Geochem. Health 42, 4213-4231.

N'guessan, Y.M., Probst, J.L., Bur, T., Probst, A., 2009. Trace elements in stream bed sediments from agricultural catchments (Gascogne Region, S-W France): where do they come from? Sci. Total Environ. 407 (8), 2939-2952. https://doi.org/10.1016/j. scitotenv.2008.12.047.

Padoan, E., Hernandez Kath, A., Vahl, L.C., Ajmone-Marsan, F., 2020. Potential release o zinc and cadmium from mine-affected soils under flooding, a mesocosm study. Arch. Environ. Contam. Toxicol. 79, 421-434.

Pickering, W.F., 1986. Metal ion speciation-soils and sediments. Ore Geol. Rev. 1, 83-146.

Provini, A., Gaggino, G.F., 1986. Depth profiles of $\mathrm{Cu}, \mathrm{Cr}$, and $\mathrm{Zn}$ in Lake Orta sediments (Northern Italy). In: Sly, Peter G. (Ed.), Sediments and Water Interactions. Springer, New York, pp. 167-174. http://link.springer.com/chapter/10.1007/978-1-4612-49 32-0_15.

Pueyo, M., Rauret, G., Lück, D., Yli-Halla, M., Muntau, H., Quevauviller, Ph., LópezSánchez, J.F., 2001. Certification of the extractable contents of $\mathrm{Cd}, \mathrm{Cr}, \mathrm{Cu}, \mathrm{Ni}, \mathrm{Pb}$ and $\mathrm{Zn}$ in a freshwater sediment following a collaboratively tested and optimised threestep sequential extraction procedure. J. Environ. Monit. 3 (2), 243-250. https://doi. org/10.1039/b010235k.

Quevauviller, Ph., 2002. Operationally-defined extraction procedures for soil and sediment analysis. Part 3: new CRMs for trace-element extractable contents. TrAC Trends Anal. Chem. 21 (11), 774-785. https://doi.org/10.1016/S0165-9936(02) 01105-6.

Quevauviller, P., Rauret, G., Muntau, H., Ure, A.M., Rubio, R., López-Sánchez, J.F., Fiedler, H.D., Griepink, B., 1994. Evaluation of a sequential extraction procedure for the determination of extractable trace metal contents in sediments. Fresenius J. Anal. Chem. 349 (12), 808-814. https://doi.org/10.1007/BF00323110.

Rauret, G., 1998. Extraction procedures for the determination of heavy metals in contaminated soil and sediment. Talanta 46 (3), 449-455. https://doi.org/10.1016/ S0039-9140(97)00406-2.

Rauret, G., López-Sánchez, J.F., Sahuquillo, A., Rubio, R., Davidson, C., Ure, A., Quevauviller, Ph., 1999. Improvement of the BCR three step sequential extraction procedure prior to the certification of new sediment and soil reference materials. J. Environ. Monit. 1 (1), 57-61. https://doi.org/10.1039/A807854H.

Robbins, J.M., Lyle, M., Heath, G.R., 1982. A Sequential Extraction Procedure for Partitioning Elements among Co-Existing Phases in Marine Sediments. College of Oceanography, Oregon State University.

Rousseau, C., Baraud, F., Leleyter, L., Gil, O., 2009. Cathodic protection by zinc sacrificial anodes: impact on marine sediment metallic contamination. J. Hazard. Mater. 167 (1-3), 953-958. https://doi.org/10.1016/j.jhazmat.2009.01.083.
Roussiez, V., Probst, A., Probst, J.-L., 2013. Significance of floods in metal dynamics and export in a small agricultural catchment. J. Hydrol. 499 (August), 71-81. https:// doi.org/10.1016/j.jhydrol.2013.06.013.

Sahuquillo, A., López-Sánchez, J.F., Rubio, R., Rauret, G., Thomas, R.P., Davidson, C.M., Ure, A.M., 1999. Use of a certified reference material for extractable trace metals to assess sources of uncertainty in the BCR three-stage sequential extraction procedure. Anal. Chim. Acta 382 (3), 317-327. https://doi.org/10.1016/S0003-2670(98) 00754-5.

Sahuquillo, A., Rigol, A., Rauret, G., 2003. Overview of the use of leaching/extraction tests for risk assessment of trace metals in contaminated soils and sediments. TrAC Trends Anal. Chem. 22 (3), 152-159. https://doi.org/10.1016/S0165-9936(03) 00303-0.

Salvarredy-Aranguren, M.M., Probst, A., Roulet, M., Isaure, M.-P., 2008. Contamination of surface waters by mining wastes in the Milluni Valley (Cordillera Real, Bolivia): mineralogical and hydrological influences. Appl. Geochem. 23 (5), 1299-1324. https://doi.org/10.1016/j.apgeochem.2007.11.019.

Seh-Bardan, B.J., Othman, R., Samsuri, A.W., Husin, A., Sadegh-Zadeh, F., 2012. Bioleaching of heavy metals from mine tailings by aspergillus fumigatus. Bioremed. J. 16 (2), 57-65. https://doi.org/10.1080/10889868.2012.665958.

Singh, K.P., Mohan, D., Singh, V.K., Malik, A., 2005. Studies on distribution and fractionation of heavy metals in Gomti River sediments-a tributary of the Ganges, India. J. Hydrol. 312 (1-4), 14-27. https://doi.org/10.1016/j.jhydrol.2005.01.021.

Slavek, J., Pickering, W.F., 1986. Extraction of metal ions sorbed on hydrous oxides of iron (III). Water Air Soil Pollut. 28 (1-2), 151-162. https://doi.org/10.1007/ BF00184077.

Snape, I., Scouller, R.C., Stark, S.C., Stark, J., Riddle, M.J., Gore, D.B., 2004. Characterisation of the dilute $\mathrm{HCl}$ extraction method for the identification of metal contamination in Antarctic marine sediments. Chemosphere 57 (6), 491-504. https://doi.org/10.1016/j.chemosphere.2004.05.042.

Sow, M.A., Payre-Suc, V., Julien, F., Camara, M., Baque, D., Probst, A., Sidibe, K, Probst, J.L., 2018. Geochemical composition of fluvial sediments in the Milo River basin (Guinea): is there any impact of artisanal mining and of a big African city, Kankan? J. Afr. Earth Sci. 145, 102-114.

Sulkowski, M., Hirner, A.V., 2006. Element fractionation by sequential extraction in a soil with high carbonate content. Appl. Geochem. 21 (1), 16-28. https://doi.org/ 10.1016/j.apgeochem.2005.09.016.

Sutherland, R.A., 2002. Comparison between non-residual Al, Co, Cu, Fe, Mn, Ni, Pb and Zn released by a three-step sequential extraction procedure and a dilute hydrochloric acid leach for soil and road deposited sediment. Appl. Geochem. 17 (4), 353-365.

Sutherland, R.A., 2010. BCR®-701: a review of 10-years of sequential extraction analyses. Anal. Chim. Acta 680 (1-2), 10-20. https://doi.org/10.1016/j. aca.2010.09.016

Sutherland, R.A., Tack, F.M.G., Ziegler, A.D., Bussen, J.O., 2004. Metal extraction from road-deposited sediments using nine partial decomposition procedures. Appl. Geochem. 19 (6), 947-955. https://doi.org/10.1016/j.apgeochem.2003.11.002.

Tessier, A., Campbell, P.G.C., Bisson, M., 1979. Sequential extraction procedure for the speciation of particulate trace metals. Anal. Chem. 51 (7), 844-851.

Ure, A.M., Davidson, C.M., Thomas, R.P., 1995. Single and sequential extraction schemes for trace metal speciation in soil and sediment. In: Maier, E.A., Griepink $\mathrm{Ph}$ Quevauviller, B. (Eds.), Techniques and Instrumentation in Analytical Chemistry, Quality Assurance for Environmental Analysis Method Evaluation within the Measurements and Testing Programme (BCR), 17. Elsevier, pp. 505-523. http:// www.sciencedirect.com/science/article/pii/S0167924406800211.

Wei, Y.-L., Yang, Y.-W., Lee, J.-F., 2005. Lead speciation in 0.1N HCl-extracted residue of analog of Pb-contaminated soil. J. Electron Spectrosc. Relat. Phenom. 144-147 (June), 299-301. https://doi.org/10.1016/j.elspec.2005.01.218.

Whalley, C., Grant, G., 1994. Assessment of the phase selectivity of the European Community Bureau of Reference (BCR) sequential extraction procedure for metals in sediment. Anal. Chim. Acta 291, 287-295.

Yeghicheyan, D., Bossy, C., Bouhnik Le Coz, M., Douchet, C., Granier, G., Heimburger, A., Lacan, F., 2013. A compilation of silicon, rare earth element and twenty-one other trace element concentrations in the natural river water reference material SLRS-5 (NRC-CNRC). Geostand. Geoanal. Res. 37 (4), 449-467. https://doi. org/10.1111/j.1751-908X.2013.00232.x.

Yokoyama, T., Makishima, A., Nakamura, E., 1999. Evaluation of the co-precipitation of incompatible trace elements with fluoride during silicate rock dissolution by acid digestion. Chem. Geol. 157, 175-187.

Yu, S., He, Z.L., Huang, C.Y., Chen, G.C., Calvert, D.V., 2004. Copper fractionation and extractability in two contaminated variable charge soils. Geoderma 123 (1-2), 163-175. https://doi.org/10.1016/j.geoderma.2004.02.003.

Yu, Z., Liu, E., Lin, Q., Zhang, E., Yang, F., Wei, C., Shen, J., 2021. Comprehensive assessment of heavy metal pollution and ecological risk in lake sediment by combining total concentration and chemical partitioning. Environ. Pollut. 269, $116-212$. 